Prepared for the U.S. Department of Energy

under Contract DE-AC05-76RL01830

\title{
Stabilization of Fast Pyrolysis Oil: Post Processing
}

DC Elliott

S-J Lee

TR Hart

March 2012

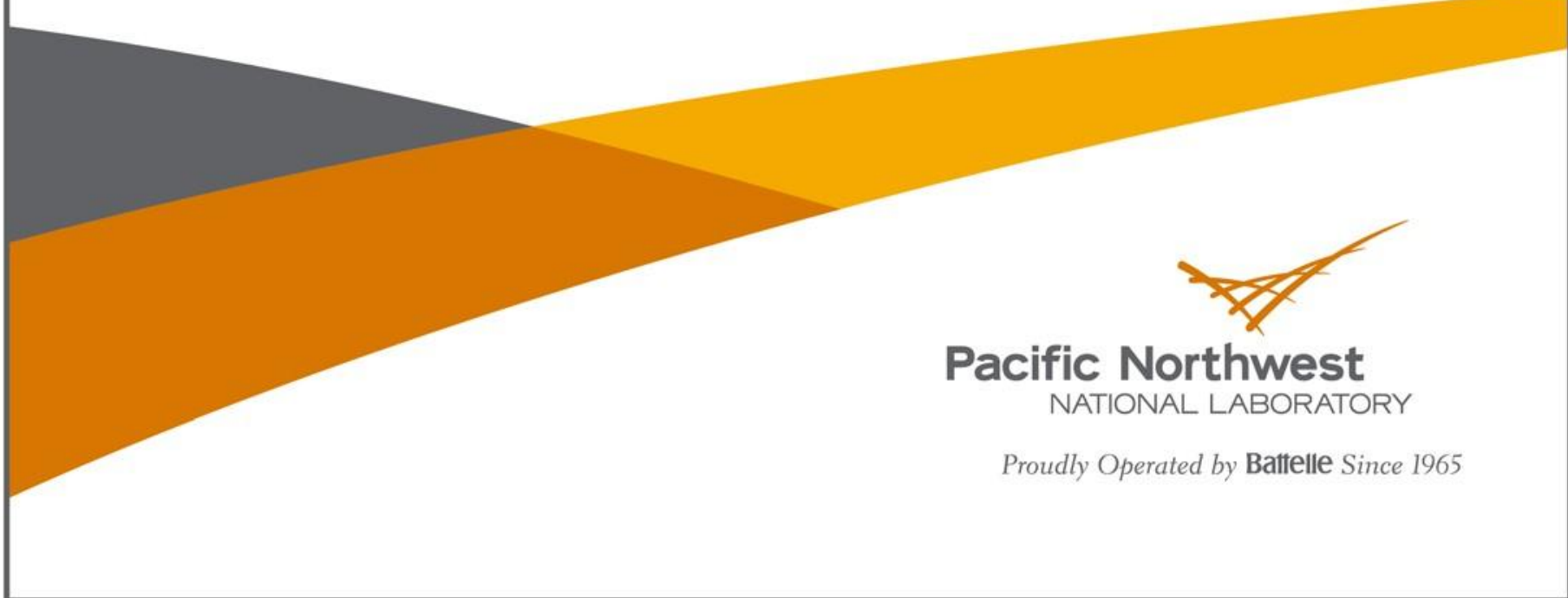




\section{DISCLAIMER}

Tllis report was prepared as an account or work sponsored by an agency or the United States Govenunent. Neither the United States Government nor any agency thereof, nor Battelle Memorial Institute, nor any of their employees, makes any wan-anty, extu-ess or imt>lied, or assumes any legal liability or responsibility for the accuracy,com(Jieteness, or usefulness of an-information, am>aratus, 1>roduct, or process disclosed, or represents that its use would not infringe 11 rivately owned tights. Reference herein to any specific commercial product, process, orSCJVicc by trade name, tmdcmark, manur;/lcturcr, orothenvisc docs not necessa rily constitute or imply its endorsement, reconunendation, or favoring by the United States Government or any agency thereof, or Battelle Memorial Institute. The views and opinions of authors expressed herein do not necessarily state or renect those of the United States Government or any agency thereof.

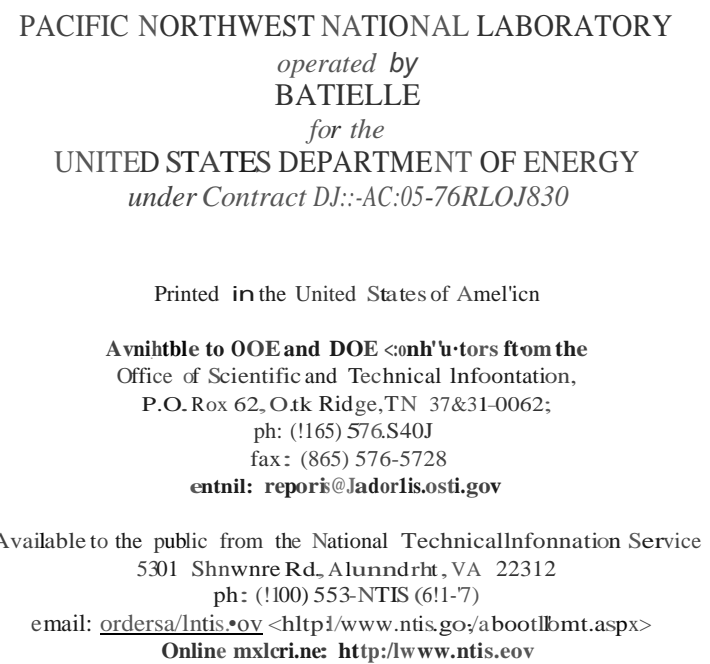

(a) Tllis document was printt:d on recycled paper.

(812010) 


\section{Stabilization of Fast Pyrolysis Oil: Post Processing}

\section{Final Report}

D. C. Elliott

S-J. Lee

T. R. Hart

March 2012

Prepared for

the U.S. Department of Energy

under Contract DE-AC06-76RL0 1830

Pacific Northwest National Laboratory

Richland, Washington 99352 


\section{Summary}

UOP LLC, a Honeywell Company, assembled a comprehensive team for a two-year project to demonstrate innovative methods for the stabilization of pyrolysis oil in accordance with DOE Funding Opportunity Announcement (FOA) DE-PS36-08GO98018, Biomass Fast Pyrolysis Oil (Bio-oil) Stabilization. In collaboration with NREL, PNNL, the USDA Agricultural Research Service (ARS), Pall Fuels and Chemicals, and Ensyn Corporation, UOP developed solutions to the key technical challenges outlined in the FOA: reduce total acid number (TAN), reduce particulate matter (char) and prevent or reduce the increase in pyrolysis oil viscosity over time, as measured by accelerated stability testing.

The UOP team proposed a multi-track technical approach for pyrolysis oil stabilization. Conceptually, methods for pyrolysis oil stabilization can be employed during one or both of two stages: (1) during the pyrolysis process ("In Process"); or (2) after condensation of the resulting vapor ("Post-Process"). Stabilization methods fall into two distinct classes: those that modify the chemical composition of the pyrolysis oil, making it less reactive; and those that remove destabilizing components from the pyrolysis oil. During the project, the team investigated methods from both classes that were suitable for application in each stage of the pyrolysis process. These specific methods were selected on the basis of prior work that had shown their potential for good performance and simple, cost-effective industrial-scale implementation.

The part of the project performed at PNNL is described in this report. The effort reported here was performed under a CRADA between PNNL and UOP, which was effective on March 13, 2009, for 2 years and was subsequently modified March 8, 2011, to extend the term to December 31, 2011.

Transfer Hydrogenation: PNNL examined catalytic transfer hydrogenation for stabilization of bio oil. PNNL performed catalyst screening, process tests and a preliminary evaluation of products via viscosity and total acid number analysis. Catalytic transfer hydrogenation is a concept that has been known for many years but has not been examined for bio-oil stabilization. It is potentially attractive as it may not require a source of high pressure, high purity hydrogen gas and likely can be employed in relatively low pressure equipment whose capital costs are low. The expected outcome of this activity was selection of a process and catalyst that would result in a stabilized bio-oil product with properties very similar to the original bio-oil, i.e. there would be minimal oxygen removal and likely no phase separation of water. However, the oil would be sufficiently stable to viscosity changes to allow for storage and transport. We first employed a series of high-throughput screening tests with a variety of conditions, donors and catalysts to select up to three appropriate combinations of these that were expected to lead to effective stabilization. The screening employed PNNL's Symyx ${ }^{\circledR}$ combinatorial high-throughput screening tool set with a six-well plate configuration.

Hydrothermal Treatment: Using existing high-pressure processing equipment, PNNL performed a series of tests to evaluate hydrothermal treatment as a means to produce a stable bio-oil product. Initial batch reactor tests were used for producing hydrothermally treated bio-oil at a range of process severity, including residence time and temperature. Using a small volume (100 $\mathrm{ml}$ ) reactor relatively quick heatup and cool down could be achieved in order to measure effects from $20 \mathrm{~min}$ to 120 minutes at temperature. Subsequent to these scouting experiments in the 
batch reactor, continuous-flow tests were also performed in existing reactor systems at PNNL. The results from the batch tests were used to guide the process parameters for the continuous flow tests. Treated product was analyzed to generate mass and elemental balances to determine deoxygenation and oxygen removal forms (carbon oxides, water). Stability of the treated bio-oil was also evaluated in terms of subsequent hydroprocessing.

The study of catalytic transfer hydrogenation for stabilizing bio-oil has not shown promise. The many combinations of donor and catalyst provided little indication of useful reaction. Although treatment with triethylsilane hydrogen donor solvent and palladium on carbon catalyst can lower the viscosity of bio-oil, the method is not considered to be economical due to the lack of an economical recycle/regeneration of the hydrogen donor.

Hydrothermal treatment of fast pyrolysis bio-oil produces "stabilized" bio-oils of inconsistent quality, possibly due to imprecise temperature measurement or inconsistent sampling due to the tendency toward inhomogeneity of the bio-oil. Clearly, more severe thermal treatment results in phase separation of the bio-oil yielding a more dense, more viscous (tar) phase and a less dense, less viscous (aqueous) phase. By careful control of the severity (residence time and temperature) the phase separation can be controlled, for the most part. A maximum allowable severity for hydrothermal treatment was found at $4 \mathrm{LHSV}$ and $100^{\circ} \mathrm{C}$, which allowed a single phase product to be recovered. The hydrothermally treated bio-oil is often (although inconsistently) more viscous than the starting bio-oil. In the thermal aging test, the hydrothermally treated bio-oil typically showed a lesser increase in viscosity (better stability). The 24-hour thermal aging test generally is functional when practiced at $80^{\circ} \mathrm{C}$ but is very inconsistent when practiced at $90^{\circ} \mathrm{C}$. At $90^{\circ} \mathrm{C}$ it often leads to phase separation so that the viscosity change cannot be determined. It was not possible to show that the hydrothermally treated bio-oil was more stable than fast pyrolysis bio-oil when processed in a fixed-bed catalytic hydrotreater to produce hydrocarbon fuel products; a pressure drop still developed over the catalyst bed during operation and evidence was found of fouling of the catalyst particles when recovered following the test. 


\section{Contents}

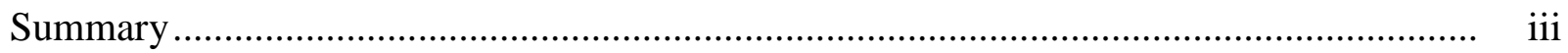

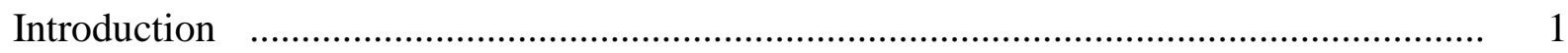

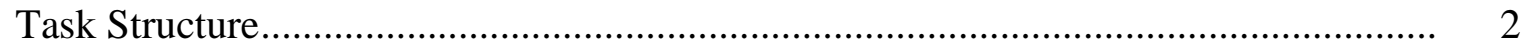

Transfer Hydrogenation ........................................................................ 2

Hydrothermal Treatment .......................................................................... 2

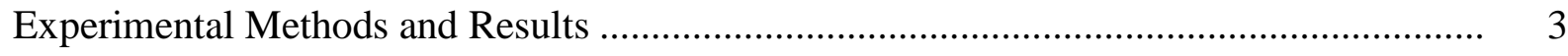

SubTask number 3.1 -Transfer hydrogenation ........................................................ 3

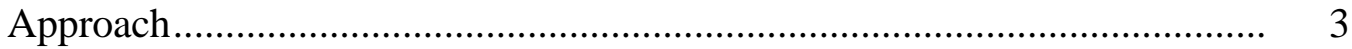

Experimental Procedure ……………………………………………...

Study Report of Triethylsiliane ............................................................... 13

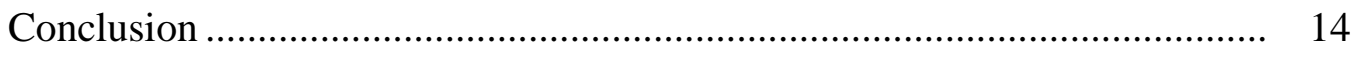

SubTask number 3.2-Hydrothermal Treatment …………………………........... 14

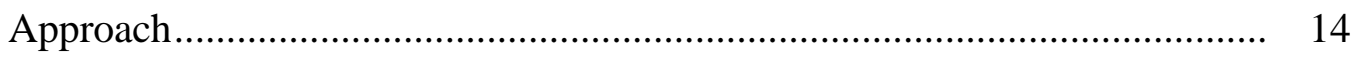

Experimental Results ......................................................................... 15

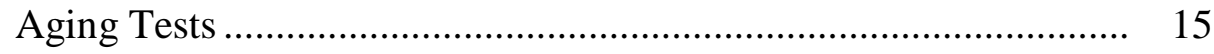

Batch Reactor Test..................................................................... 16

Continuous-Flow Reactor Tests.................................................... 17

Hydroprocessing of Hydrothermal Treatment Products ................... 18

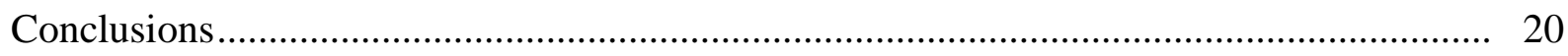

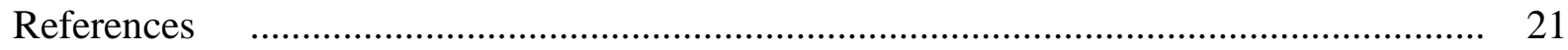




\section{Figures}

1 Overview of opportunities for pyrolysis stabilization ….................................. 1

2 Schematic of bench-scale hydrotreater at PNNL .............................................. 19

\section{Tables}

1 Pyrolysis Oil Stabilization Technology Matrix ................................................... 2

2 Viscosity Measurements of Treated Bio-oil with Various Hydrogen Donors ............ 5

3 Stock Solutions Used in Second Series of Combi Tests........................................ 6

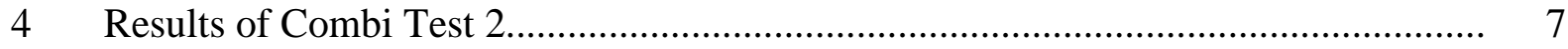

$5 \quad$ Experimental Matrix for 3rd Combi Test ......................................................... 8

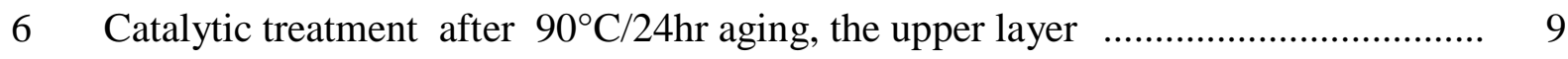

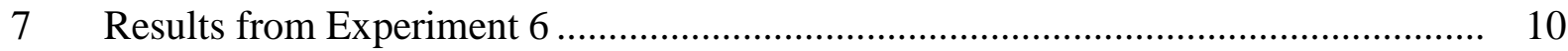

8 Elemental Analysis of Bio-oil, Treated and Untreated with TES............................ 11

$9 \quad{ }^{13} \mathrm{C}$ NMR Analysis of Bio-oil, Treated and Untreated with TES ........................... 11

10 Qualitative Analysis by GC-MS of Blank (w/o TES) Bio-oil ................................ 12

11 Qualitative Analysis by GC-MS of TES treated Bio-oil ..................................... 13

12 Stability test per standard aging method ...................................................... 15

13 Extended Time Results for Viscosity Measurement ........................................ 16

14 Stability Test for Alkali Hydrothermally-Treated Products ................................. 17

15 Qualitative Analysis by GC-MS of TES treated Bio-oil ....................................... 18

16 Results of Analyses of Samples from Continuous Flow Tests ............................... 18

17 Results from Long-Term Continuous Flow Test, $76.3 \mathrm{hr}$ on stream ........................ 19

18 Results of Hydrotreating Hydrothermally-treated Bio-oil ..................................... 20 


\section{Introduction}

Project Title: $\quad$ Stabilization of Fast Pyrolysis Oil: Post Processing for Bio-oil Stabilization Award Number: $\quad 3.2 .2 .15-18636$

CRADA Number: PNNL/287

Subject Inventions: None.

Publications / Presentations: At the Thermochemical Conversion Sciences 2010 conference in Ames, Iowa, September 23, 2010, Tim Brandvold of UOP made the group presentation, which included some of these results.

UOP LLC, a Honeywell Company, assembled a comprehensive team for a two-year project to demonstrate innovative methods for the stabilization of pyrolysis oil in accordance with DOE Funding Opportunity Announcement (FOA) DE-PS36-08GO98018, Biomass Fast Pyrolysis Oil (Bio-oil) Stabilization. In collaboration with NREL, PNNL, the USDA Agricultural Research Service (ARS), Pall Fuels and Chemicals, and Ensyn Corporation, UOP proposed to develop solutions to the key technical challenges outlined in the FOA: reduce total acid number (TAN), reduce particulate matter (char) and prevent or reduce the increase in pyrolysis oil viscosity over time, as measured by accelerated stability testing.

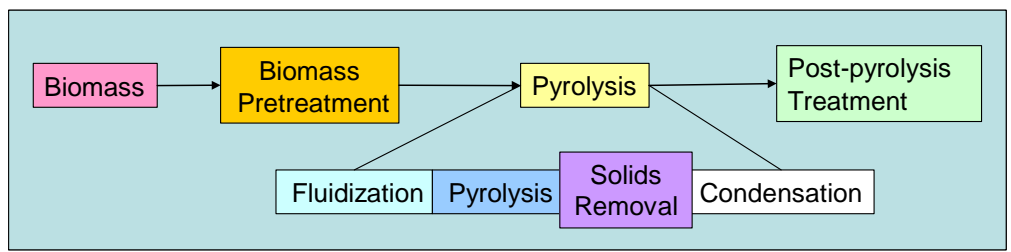

Figure 1. Overview of opportunities for pyrolysis stabilization

The UOP team proposed a multi-track technical approach for pyrolysis oil stabilization. Conceptually, methods for pyrolysis oil stabilization could be employed during one or both of two stages: (1) during the pyrolysis process ("In Process"); or (2) after condensation of the resulting vapor ("Post-Process"). Stabilization methods fall into two distinct classes: those that modify the chemical composition of the pyrolysis oil, making it less reactive; and those that remove destabilizing components from the pyrolysis oil. During the proposed project, the team investigated methods from both classes that were suitable for application in each stage of the pyrolysis process, as summarized in Table 1. These specific methods were selected on the basis of prior work that had shown their potential for good performance and simple, cost-effective industrial-scale implementation.

The effort described in this report was performed under a CRADA between PNNL and UOP, which was effective on March 13, 2009, for 2 years and was subsequently modified March 8, 2011, to extend the term to December 31, 2011. 
Table 1. Pyrolysis Oil Stabilization Technology Matrix

\begin{tabular}{|c|c|c|}
\hline & $\begin{array}{l}\text { In-Process } \\
\text { (gas phase) }\end{array}$ & $\begin{array}{l}\text { Post-Process } \\
\text { (liquid phase) }\end{array}$ \\
\hline $\begin{array}{l}\text { Modify } \\
\text { chemical } \\
\text { composition }\end{array}$ & $\begin{array}{l}\text { Catalytic Pyrolysis } \\
\text { (Task 1.1) } \\
\text { Operational } \\
\text { Modifications } \\
\text { (Task 1.2) }\end{array}$ & $\begin{array}{l}\text { Transfer } \\
\text { Hydrogenation } \\
\text { (Task 3.1) PNNL } \\
\text { Hydrothermal } \\
\text { Treatment } \\
\text { (Task 3.2) PNNL }\end{array}$ \\
\hline $\begin{array}{l}\text { Remove } \\
\text { destabilizing } \\
\text { components }\end{array}$ & $\begin{array}{l}\text { Hot Gas Filtration } \\
\text { (Task 2) } \\
\text { Selective Fractionation } \\
\text { (Task 3.4) }\end{array}$ & $\begin{array}{l}\text { Liquid Filtration } \\
\text { (Task 3.3) } \\
\text { Selective Fractionation } \\
\text { (Task 3.4) }\end{array}$ \\
\hline
\end{tabular}

A kick-off meeting on February 27, 2009, was attended at UOP to coordinate activities with the other project partners.

Initial activities undertaken to prepare for the transfer hydrogenation tests included a literature search, purchase of catalysts and chemicals, and check-out of the testing equipment. The batch reactor was set-up and checked in preparation for the hydrothermal tests.

The bio-oil feedstock used in these tests was the Kentucky oak fast pyrolysis bio-oil provided by NREL to all participants in the projects funded under DOE FOA DE-PS36-08GO98018. It was shipped from NREL on May 18, 2009.

\section{Task Structure}

Transfer Hydrogenation: PNNL examined catalytic transfer hydrogenation for stabilization of bio oil. PNNL performed catalyst screening, process tests and a preliminary evaluation of products via viscosity and total acid number analysis. Catalytic transfer hydrogenation is a concept that has been known for many years but has not been examined for bio-oil stabilization. It is potentially attractive as it may not require a source of high pressure, high purity hydrogen gas and likely can be employed in relatively low pressure equipment whose capital costs are low. The expected outcome of this activity was selection of a process and catalyst that results in a stabilized bio-oil product with properties very similar to the original bio-oil, i.e. there is minimal oxygen removal and likely no phase separation of water. However, the oil will be sufficiently stable to viscosity changes to allow for storage and transport. First, a series of high-throughput screening tests with a variety of conditions, donors and catalysts were employed to select up to three appropriate combinations of these that were expected to lead to effective stabilization. The screening employed PNNL's Symyx ${ }^{\circledR}$ combinatorial high-throughput screening tool set with a six-well plate configuration.

Hydrothermal Treatment: Using existing high-pressure processing equipment, PNNL performed a series of tests to evaluate hydrothermal treatment as a means to produce a stable bio-oil product. Initial batch reactor tests were used for producing hydrothermally treated bio-oil at a range of process severity, including residence time and temperature. Using a small volume (100 
$\mathrm{ml}$ ) reactor relatively quick heatup and cool down was achieved in order to measure effects from $20 \mathrm{~min}$ to $120 \mathrm{~min}$ at temperature. Subsequent to these scouting experiments in the batch reactor, continuous-flow tests were also performed in existing reactor systems at PNNL. The results from the batch tests were used to guide the process parameters for the continuous flow tests. Treated product was analyzed to generate mass and elemental balances to determine deoxygenation and oxygen removal forms (carbon oxides, water). Stability of the treated bio-oil was also evaluated in terms of subsequent hydroprocessing.

\section{Experimental Methods and Results}

\section{SubTask number: 3.1 - Transfer Hydrogenation}

Approach: Transfer hydrogenation is an alternative to the conventional hydrogenation which often involves extreme pressure, temperature and hydrogen sources. Transfer hydrogenation is a catalytic addition of hydrogen from a non-gaseous hydrogen source called reducing agent or hydrogen donor. The catalytic transfer hydrogenation is feasible using a mild and safe operation and has been widely used in industry and in organic synthesis, for example, asymmetric transfer hydrogenation in the pharmaceutical field. One large scale application of transfer hydrogenation is coal liquefaction using tetralin as a "donor solvent". ${ }^{i}$ The most significant development of transfer hydrogenation is the enantioselectivity in homogenous asymmetric reductions used for organic syntheses, although the asymmetric selectivity of transfer hydrogenation is not required for stabilizing the crude bio-oil. Commonly used metals for heterogeneous and homogeneous catalytic transfer hydrogen are palladium, ruthenium, rhodium, iridium and nickel. Recognized reducing agents include using formic acid to form formate salts, alcohols to form ketones (isopropanol to acetone), diimide from hydrazine $\left(\mathrm{N}_{2} \mathrm{H}_{2}\right.$ from $\left.\mathrm{N}_{2} \mathrm{H}_{4}\right)$, and the formation of alkane/benzene by gaining aromatic stabilization energy.

A number of studies on selective reduction of several important functional groups by catalytic transfer hydrogenation using ammonium formate and palladium or nickel have been reported. These include the reactions of the heterocyclic ring in quinolines ${ }^{\text {ii }}$, reduction of aryl ketones to alcohols ${ }^{\mathrm{iii}}$, benzyl hydrogenolysis of dibenzyl uracils ${ }^{\mathrm{iv}}$, reduction of nitro compounds to the amines $^{\mathrm{v}}$, deoxygenation of aromatic nitric oxides ${ }^{\mathrm{vi}}$, and reduction of the double bond in conjugation with a carbonyl moiety ${ }^{\mathrm{vii}}$. Raney nickel was used for reduction of carbonyl compounds and aryl ketones. ${ }^{\text {iv, viii }} \mathrm{Rh}$ (III) and $\mathrm{Ru}$ (II) coupled with formate or 2-propanol are considered as the active species for homogenous asymmetric transfer hydrogenation of aldehydes and ketones. ${ }^{\text {ix }}$

Experimental Procedure: The experimental process involved testing the reaction of various catalysts and reducing agents with bio-oil under mild conditions.

1. Screening tests of catalysts and hydrogen donors were performed using a high throughput system. All the catalysts selected for the screening test were activated with hydrogen flow at $100^{\circ} \mathrm{C}$ for $2 \mathrm{hr}$ prior to use. All the reactions were carried out under atmospheric pressure at room temperature and $80^{\circ} \mathrm{C}$ for $5 \mathrm{hrs}$. 
2. Aging assessment: After the treatments the catalysts were removed from the bio-oil samples by centrifuging at $2000 \mathrm{rpm}$ for an hour. All the samples were heated at $90^{\circ} \mathrm{C}$ for $24 \mathrm{hr}$ in sealed jars.

3. Sample analyses: viscosity of each sample was determined by viscometer and served as the qualification of whether the catalytic process took place. The kinematic viscosity was measured at $40^{\circ} \mathrm{C}$ and recorded as centistokes, cSt.

4. Data evaluation: discussion of results.

\section{Experiment 1:}

Twelve catalysts were used in the screening test. All are carbon supported except the Sud Chemie nickel is on a proprietary oxide support.
1. $10 \%$ Pd-Degussa
7. $5 \%$ Ru-Alfa Aeser
2. $10 \%$ Pd-BASF1
8. $\quad 5 \%$ Ru-Engelhard
3. $10 \%$ Pd-BASF2
9. $5 \%$ Rh-Johnson Matthey
4. $50 \%$ Ni-Sud Chemie
10. $5 \%$ Rh-Degussa
5. $5 \% \mathrm{Pt}-$ Strem
11. $5 \% \mathrm{Pd}+5 \% \mathrm{Ru}$-Engelhard
6. $5 \%$ Pt-Engelhard
12. $5 \% \mathrm{Pd}+5 \% \mathrm{Rh}$-Engelhard

The three hydrogen donors used were ammonium formate, hydrazine dihydrochloride, and isopropanol. Ammonium formate and hydrazine dihydrochloride were dissolved in methanol.

The reaction sample contained $2 \mathrm{ml}$ of bio-oil, $0.25 \mathrm{~g}$ of catalyst and $0.5 \mathrm{ml}$ of H-donor. Blank samples, without hydrogen donor, were also processed under the same conditions.

Results and Observations:

1. It was observed that propanol alone diluted the bio-oil $(21.94 \mathrm{cSt}, 0.94 \mathrm{~g} / \mathrm{ml})$ as did methanol $(15.6 \mathrm{cSt}, 0.94 \mathrm{~g} / \mathrm{ml})$. The similar results following reaction suggested only dilution happened and no significant catalytic hydrogen transfer reactions occurred. The measurement of viscosity after catalytic treatment is shown in Table 2.

2. There were two layers observed before centrifuging. It was found that the H-donors and bio-oil didn't mix well, which likely limited reaction.

3. Methanol is poor solvent for the hydrogen donors. The desired concentration of $\mathrm{H}$-donor is around $1.3 \mathrm{mmol}$; however, the solubility of hydrazine dihydrochloride is $<0.02 \mathrm{mmol}$ in $\mathrm{CH}_{3} \mathrm{OH}$.

4. Density correction is necessary for each sample.

\section{Discussion:}

The starting bio-oil sample was quantified as $52.28 \mathrm{cSt}$ before aging at $90^{\circ} \mathrm{C}$ for 24 hours and $71.4 \mathrm{cSt}$ after. The results of catalytic transfer hydrogenation were not very promising or clear. The hydrogen donor, ammonium formate in methanol, even increased the viscosity to $>300 \mathrm{cSt}$. 
Table 2. Viscosity Measurements of Treated Bio-oil with Various Hydrogen Donors

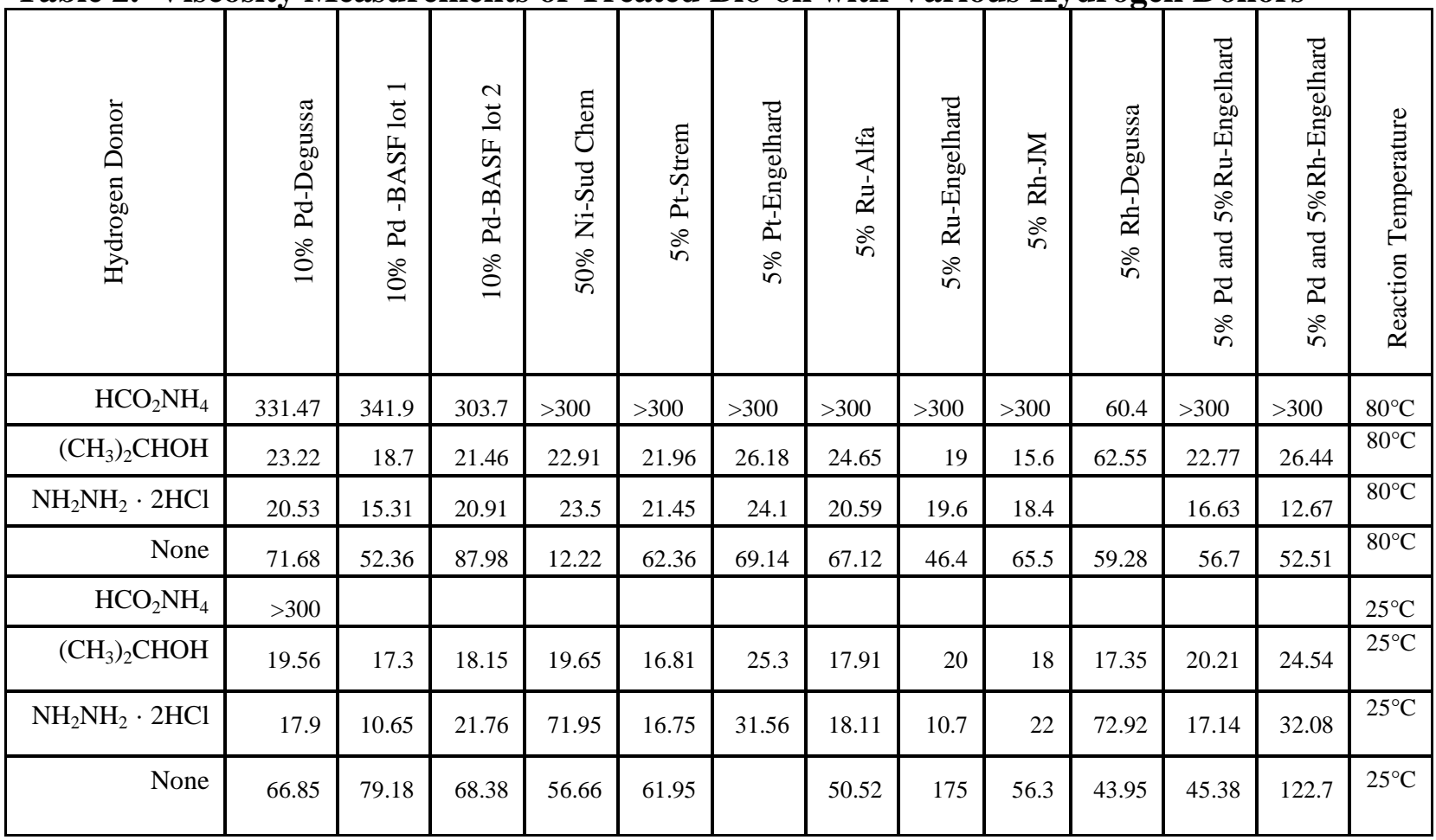

Although the viscosities by using different hydrogen donors, isopropanol and hydrazine dihydrochloride, were significantly reduced compared to the untreated sample $(71.4 \mathrm{cSt})$, the change is likely due to the dilution by the added solvents, isopropanol and methanol. An addition of $0.5 \mathrm{ml}$ of propanol and methanol to $2 \mathrm{ml}$ of bio-oil gave a viscosity of $21.94 \mathrm{cSt}$ from propanol dilution and $15.6 \mathrm{cSt}$ from methanol dilution with a density of $0.94 \mathrm{~g} / \mathrm{ml}$. It was found that the solubility of hydrazine dihydrochloride in methanol was very small $(<0.02 \mathrm{mmol})$.

It was noticed that the catalysts were not well mixed with bio-oil sample in the reaction cells due to the small sample volume of the $96 \mathrm{X}$ plate in the combi reactor.

A few suggested techniques were identified to improve and clarify the raw data such as using bigger reaction cells $(20 \mathrm{ml}$ vs. $3 \mathrm{ml})$ to increase the contact of catalyst and bio-oil, density correction of each sample to account for the variation of sample dilution, and searching for new hydrogen donors. The solvent dilution problem could be minimized by using more concentrated hydrogen donor so that only a small amount of liquid solvent would need to be added to the reaction. In order to clarify the activities of catalysts, the use of hydrogen as hydrogen donor was also suggested.

Experiment 2:

The second screening tests were intended to correct the addressed problems in the first set of Combi tests. The problems included improper mixing of catalysts and oil samples and the solvent dilution problem in which methanol/isopropanol were used as solvents of hydrogen donors. The addition of solvent also altered the density of the bio-oil. It was found that hydrazine $2 \mathrm{HCl}$ and ammonium formate were inadequate due to the poor solubility in methanol. The second experiment also included reexamination of the activity of the selected catalysts. 
The modifications of the second set included the use of the bigger sample vessels (20 ml vs. 4 $\mathrm{ml}$ ) to improve the mixing between catalyst and hydrogen donors, change of hydrogen donor solvent by dissolving hydrogen donors in $\mathrm{H}_{2} \mathrm{O}$ and introducing only $1 \%$ aqueous solutions to the samples to avoid the additional solvent dilution and variation of the density for each sample. The activities of the catalyst and supporting material were tested by treating with hydrogen with a pressure of $1000 \mathrm{psi}$. The four reactors of the combi system were run at $80^{\circ} \mathrm{C}$ for $5 \mathrm{hr}$ and were designed as:

Reactor A: 12 catalyst and 12 supporting materials: each $4 \mathrm{ml}$ vial contained $2 \mathrm{ml}$ of oil, $0.25 \mathrm{~g}$ catalyst or $0.25 \mathrm{~g}$ of supporting materials and hydrogen at $1000 \mathrm{psi}$ using as hydrogen donor.

Reactor B: 6 catalysts and $50 \mu \mathrm{l}$ of $10 \mathrm{M}$ ammonium formate; each $20 \mathrm{ml}$ vial contained $5 \mathrm{ml}$ of oil sample, $0.3 \mathrm{~g}$ of catalyst.

Reactor C: 6 catalysts with $50 \mu \mathrm{l}$ of ammonium formate $(10 \mathrm{M}) / 40 \mu \mathrm{l}$ of $10 \mathrm{M} \mathrm{NaOH}$; each $20 \mathrm{ml}$ vial contained $5 \mathrm{~mL}$ of oil sample, $0.3 \mathrm{~g}$ of catalysts.

Reactor D: 5 hydrogen donors and one blank; each $20 \mathrm{ml}$ vial contained $5 \mathrm{~mL}$ of oil, $50 \mu \mathrm{l}$ of each hydrogen donor and $50 \mu \mathrm{L}$ of $\mathrm{H}_{2} \mathrm{O}$. Five hydrogen donors were ammonium formate, ammonium formate $+\mathrm{NaOH}$, cesium formate, $\mathrm{H}_{2} \mathrm{NNH}_{2} \cdot 2 \mathrm{HCl}$ and formic acid. $\mathrm{H}_{2} \mathrm{O}$ was added to the bio-oil in the blank test because all the hydrogen donors were dissolved in water. However, hydrazine was not very soluble in $\mathrm{H}_{2} \mathrm{O}$.

The stock solutions of each hydrogen donor were prepared prior to use as shown in Table 3.

Table 3. Stock Solutions Used in Second Series of Combi Tests

\begin{tabular}{|l|l|r|r|l|l|l|}
\hline & CAS & FW & Density & Mass (5 mmole) & $\mathrm{H}_{2} \mathrm{O}$ & conc. \\
\hline Ammonium Formate & $540-69-2$ & 63.06 & & $316 \mathrm{mg}$ & $0.5 \mathrm{ml}$ & $10 \mathrm{M}$ \\
\hline Cesium Formate & $3495-36-1$ & 177.92 & & $890 \mathrm{mg}$ & $0.5 \mathrm{ml}$ & $10 \mathrm{M}$ \\
\hline $\mathrm{H}_{2} \mathrm{NNH}_{2} \cdot 2 \mathrm{HCl}$ & $5341-61-7$ & 104.97 & & $524 \mathrm{mg}$ & $0.5 \mathrm{ml}$ & $10 \mathrm{M}$ \\
\hline Formic Acid & $64-18-6$ & 46.03 & 1.22 & $230 \mathrm{mg}(188.6 \mathrm{ul})$ & $0.5 \mathrm{ml}$ & $10 \mathrm{M}$ \\
\hline
\end{tabular}

Results and Observations:

The Reactor A test was run at $80^{\circ} \mathrm{C}$ for over $17 \mathrm{hr}$ instead of the planned $5 \mathrm{hr}$ due to the failure of instrumental control. However, all the samples were continued through the procedure and aged at $90^{\circ} \mathrm{C}$ for $24 \mathrm{hr}$.

A new viscometer was purchased and used for samples from Experiment 2. The new Stabinger Viscometer was installed and calibrated.

Viscosity of control sample at $40^{\circ} \mathrm{C}$ :

1. Before reaction/inside the glove box (degassed): $71.855 \mathrm{~mm}^{2} / \mathrm{s}$; density: $1.2254 \mathrm{~g} / \mathrm{ml}$

2. After reaction and aging: $127.025 \mathrm{~mm}^{2} / \mathrm{s}$; density: $1.2089 \mathrm{~g} / \mathrm{ml}$

Other results were estimated relative to the blank $\left(127.025 \mathrm{~mm}^{2} / \mathrm{s}\right)$ after reaction because the sample volume after catalyst removal was not enough for the measurement. The new viscometer required more than $5 \mathrm{ml}$ of sample per test. The results are given in Table 4, with blank cells 
indicating no test made with that combination. The estimate of the amount of change of viscosity is indicated, relative to the blank. The ppt indicates a precipitate occurred.

Table 4. Results of Combi Test 2.

\begin{tabular}{|c|c|c|c|c|c|c|c|c|c|c|c|c|c|c|}
\hline $\begin{array}{l}\text { Rough } \\
\text { Composition } \\
6 \% \text { catalyst to } \\
\text { feed }\end{array}$ & 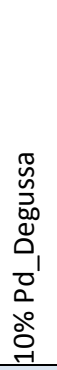 & 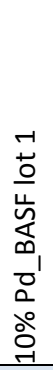 & 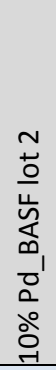 & 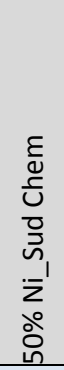 & 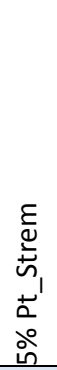 & 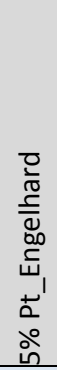 & 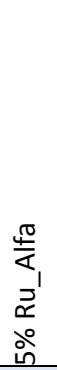 & 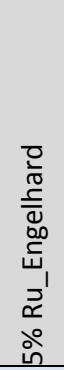 & 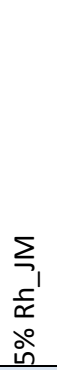 & 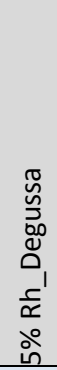 & 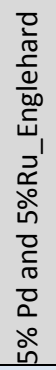 & 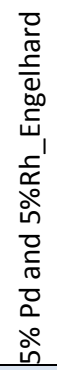 & 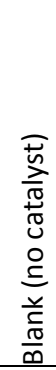 & 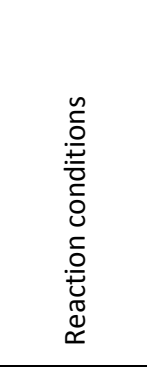 \\
\hline Hydrogen & 0 & $<<$ & $<$ & ppt & $<$ & $<$ & $<$ & ppt & $<$ & $\ll$ & $\ll$ & ppt & & $80^{\circ} \mathrm{C} / 12 \mathrm{~h}$ \\
\hline $\begin{array}{r}\text { Ammonium } \\
\text { Formate }\end{array}$ & & & ppt & ppt & & ppt & & ppt & & ppt & 0 & $>$ & ppt & $80^{\circ} \mathrm{C} / 12 \mathrm{~h}$ \\
\hline $\begin{array}{r}\text { Ammonium } \\
\text { Formate/ } \mathrm{NaOH}\end{array}$ & & & $\mathrm{ppt}$ & $\mathrm{ppt}$ & & $\mathrm{ppt}$ & & ppt & & $\mathrm{ppt}$ & ppt & & $\mathrm{ppt}$ & $80^{\circ} \mathrm{C} / 12 \mathrm{~h}$ \\
\hline Cesium Formate & & & & & & & & & & & & & $\mathrm{ppt}$ & $80^{\circ} \mathrm{C} / 12 \mathrm{~h}$ \\
\hline Hydrazine $2 \mathrm{HCl}$ & & & & & & & & & & & & & ppt & $80^{\circ} \mathrm{C} / 12 \mathrm{~h}$ \\
\hline Formic Acid & & & & & & & & & & & & & $<$ & $80^{\circ} \mathrm{C} / 12 \mathrm{~h}$ \\
\hline Blank( no donor) & & & & & & & & & & & & & 0 & $80^{\circ} \mathrm{C} / 12 \mathrm{~h}$ \\
\hline
\end{tabular}

The results suggested that three out of 12 catalysts were not active. They are 50\% Ni from Sud $\mathrm{Chem}, 5 \% \mathrm{Ru}$ from Engelhard and 5\% Pd+5\%Rh from Engelhard. None of the hydrogen transfer systems eliminated the increase of viscosity after aging. The ammonium formate and its base addition were not a good hydrogen donor system with any of 12 catalysts. The other hydrogen donors, cesium formate and hydrazine $2 \mathrm{HCl}$, without catalysts, resulted in an increase in the viscosity in the aging test. Formic acid without catalyst might be able to prevent the increase of viscosity. The further investigation of formic acid for stabilization of bio-oil was suggested.

\section{Experiment 3: Addition of solid Hydrogen donor/Reducing agent to Bio-oil}

$\mathrm{NaBH}_{4}$ is a common reducing agent and might be a good solid hydrogen donor for stabilization of bio-oil. It is reported that $\mathrm{NaBH}_{4}$ is a better reducing agent under basic conditions, so $\mathrm{Na}_{2} \mathrm{CO}_{3}$ was added to the reaction as well. The molar ratio of $\mathrm{NaBH}_{4} / \mathrm{Na}_{2} \mathrm{CO}_{3}=1: 1$ in the test where it was added.

$10 \% \mathrm{NaBH}_{4}$ of bio-oil by weight was used. Bio-oil density was measured as $1.21 \mathrm{~g} / \mathrm{ml}$.

Actual measurements included $2 \mathrm{ml}$ of bio-oil / $0.24 \mathrm{~g}$ of $\mathrm{NaBH}_{4} / 0.338 \mathrm{~g}$ of $\mathrm{Na}_{2} \mathrm{CO}_{3}$

Four samples were planned to run:
a. Blank (2 $\mathrm{ml}$ of bio-oil);
b. $2 \mathrm{ml}$ of oil $+0.5 \mathrm{ml} \mathrm{MeOH}$;
c. $2 \mathrm{ml}$ of oil $+\mathrm{NaBH}_{4}+\mathrm{Na}_{2} \mathrm{CO}_{3}$; 


\section{d. $\mathrm{NaBH}_{4} / \mathrm{MeOH}+2 \mathrm{ml}$ bio-oil}

In the case of sample d, however, the $\mathrm{NaBH}_{4}$ reacted with $\mathrm{CH}_{3} \mathrm{OH}$ violently releasing $\mathrm{H}_{2}$. The strong reaction was moderated by the use of a very small amount of $\mathrm{NaBH}_{4}(16 \mathrm{mg})$. The reaction proceeded vigorously when $2 \mathrm{ml}$ of bio-oil was added to $16 \mathrm{mg}$ of $\mathrm{NaBH}_{4}$ and gas $\left(\mathrm{H}_{2}\right)$ formed immediately. This sample was not considered further.

Three samples (a. blank, b. oil- $\mathrm{CH} 3 \mathrm{OH}$ and c. oil- $\mathrm{NaBH}_{4}$ ) were shaken for one hour at room temperature.

Result:

Viscosity of bio-oil before treatment: Blank $=43.3 \mathrm{cSt}\left(52.4 \mathrm{~mm}^{2} / \mathrm{sec}\right)$

Viscosity of bio-oil after treatment: Blank=43.8 cSt; $\mathrm{MeOH}$ addition= 15.4cSt;

$\mathrm{NaBH}_{4}$ addition $=57.9 \mathrm{cSt}$.

The effect on the viscosity by the addition of the reagents obviously made interpretation of these results difficult.

Experiment 4: Continuous screening tests of catalyst-hydrogen donor

A third set of combi tests was undertaken as shown in Table 5. The two hydrogen donors, formic acid, and cesium formate were evaluated with 10 catalysts. The reaction was carried out at $80^{\circ} \mathrm{C}$ for $5 \mathrm{hr}$.

Table 5. Experimental Matrix for 3rd Combi Test.

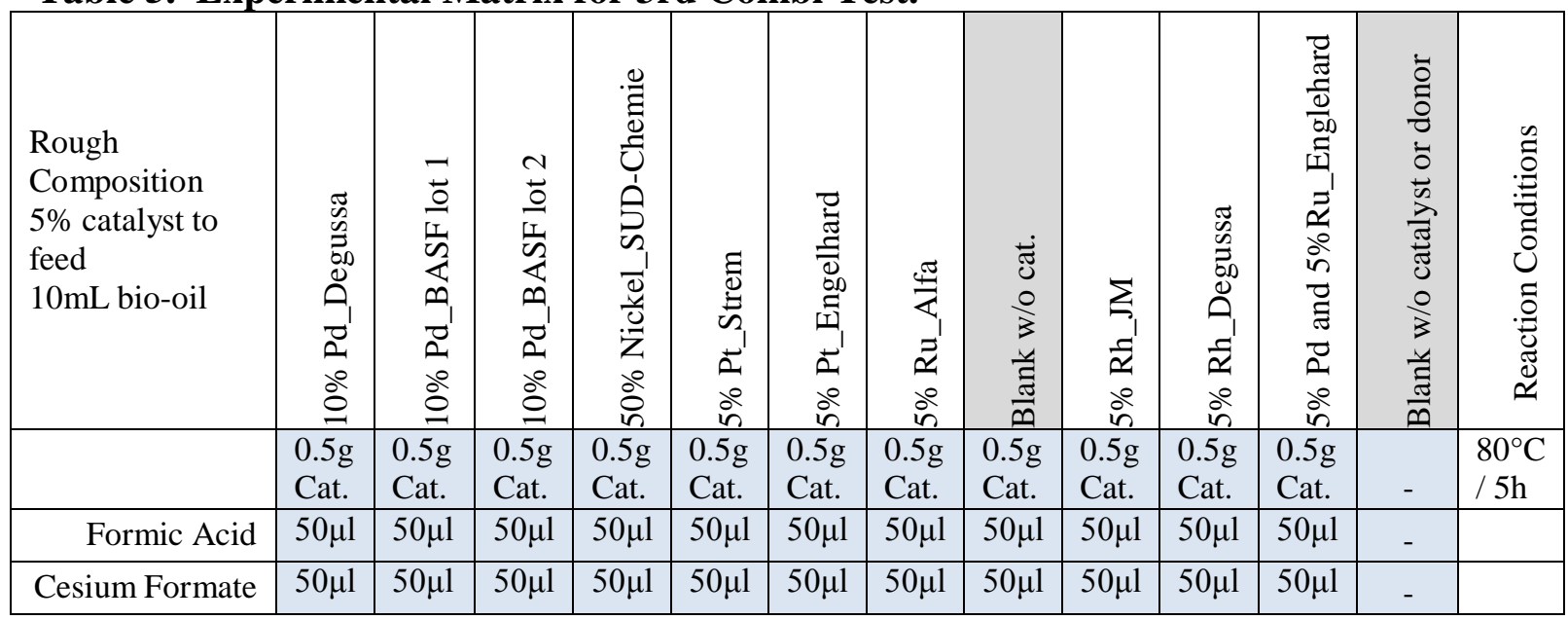

Result:

The blank was determined as $45.213 \mathrm{cSt}(1.211 \mathrm{~g} / \mathrm{ml})$. Phase separation was observed in all samples with donor and catalyst. The upper layer had a viscosity around $12.5 \mathrm{cSt}(1.194 \mathrm{~g} / \mathrm{ml})$. The viscosity of the bottom layer was $>300 \mathrm{cSt}$. Because of the phase separation, no further analysis was done. 
Experiment 5: Investigation of more hydrogen donors

Tetralin and triethylsilane coupling with $\mathrm{Pd} / \mathrm{C}$ were referenced in many instances in the literature. Triethylsilane (TES) has been reported as a hydrogen donor with $\mathrm{Pd} / \mathrm{C}$ in catalytic transfer hydrogenation for the reductions of multiple bonds, nitro groups, azides, benzyl/allyl deprotection, etc. ${ }^{\mathrm{x}}$ TES also was used with other metal catalysts such as Ru Grubbs-type for a combined metathesis and olefin hydrogenation. ${ }^{\mathrm{xi}}$

It seems both tetralin and triethylsilane (TES) have great potential to stabilize crude bio-oil after a quick test. It was observed the viscosity was greatly reduced even after a $90^{\circ} \mathrm{C}, 24 \mathrm{hr}$ aging.

Additional analyses, ${ }^{13} \mathrm{C}$ Nuclear Magnetic Resonance (NMR) spectra and gas chromatography/mass spectrometry (GC/MS) would provide better chemistry information relative to viscosity.

Results and Observations:

Five different Pd on carbon catalysts were tested for reducing the viscosity of bio-oil with TES. For each catalyst, $0.5 \mathrm{ml}(3 \% \mathrm{wt})$ of triethylsilane was syringed to $10 \mathrm{~g}$ of bio-oil with $10 \mathrm{wt} \%$ catalyst. The reaction mixture was stirred for 20 minutes under $\mathrm{N}_{2}$. The catalysts were removed by centrifugation. The bio-oil samples then were aged at $90^{\circ} \mathrm{C}$ for $24 \mathrm{hr}$. The viscosity of all biooil samples, as reported in Table 6, was reduced $45 \%$ to $55 \%$ comparing to a blank sample. Because TES is immiscible with bio-oil, the decrease of viscosity is not the result of sample dilution, as shown by the result with addition of TES only. A similar set of experiments with tetralin suggested no hydrogen donor effect, only the simple dilution of the bio-oil by the tetralin as shown by the result with addition of tetralin only.

\begin{tabular}{||l|l||l|l|}
\hline \multicolumn{2}{|l|}{ Table 6. Measurement of the Upper Layer Recovered after Catalytic Treatment } \\
\hline Conditions & $\begin{array}{l}\text { Triethylsilane } \\
\text { (viscosity/density) }\end{array}$ & Conditions & $\begin{array}{l}\text { Tetralin } \\
\text { (viscosity/density) }\end{array}$ \\
\hline Blank w/o donor & $17.468 / 1.193$ & Blank w/o donor & $20.206 / 1.198$ \\
\hline TES only & $18.631 / 1.190$ & Tetralin only & $13.317 / 1.191$ \\
\hline $10 \%$ Pd-C Engelhard & $8.6492 / 1.176$ & $10 \%$ Pd-C BASF 1 & $11.695 / 1.191$ \\
\hline $5 \%$ Pd-C & $8.2348 / 1.175$ & $10 \%$ Pd-C BASF 2 & $13.088 / 1.192$ \\
\hline $10 \%$ Pd-C & $8.6811 / 1.178$ & Pt-C Strem & $13.424 / 1.193$ \\
\hline $5 \%$ Pd-C & $8.9308 / 1.177$ & Pt-C Engelhard & $13.835 / 1.194$ \\
\hline $10 \%$ Pd-C & $7.300 / 1.172$ & Rh-C JM & $12.749 / 1.193$ \\
\hline & & Rh-C Degussa & $14.082 / 1.192$ \\
\hline
\end{tabular}

It was noted that hydrogen gas was formed immediately when TES was added to $5 \% \mathrm{Pd} / \mathrm{C}$ or $10 \% \mathrm{Pd} / \mathrm{C}$ at room temperature. However, the hydrogen evolution was not observed when TES coupled with other metals, (Rh, Ru or $\mathrm{Pt}$ ) or metal oxides $(\mathrm{Ni}, \mathrm{Cr}, \mathrm{Cu})$.

Additional experiments were conducted to understand the chemistry of TES with $\mathrm{Pd} / \mathrm{C}$ and biooil. The proton NMR spectra showed the identical chemical shifts for the ethyl groups in the TES before and after reacting with $\mathrm{Pd} / \mathrm{C}$. This suggests that two TES molecules gave up the lone 
hydrogen to form a Si-Si bond and release a $\mathrm{H}_{2}$. Due to the complexity of the bio-oil, the path way of this interaction is still unclear.

The proposed mechanism of hydrogen formation by TES coupling with $\mathrm{Pd} / \mathrm{C}$.

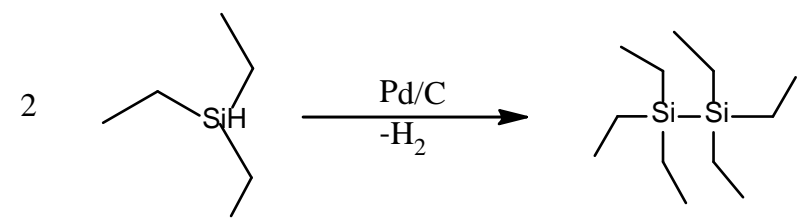

Experiment 6: Study of triethylsilane coupling with palladium on carbon

More studies of the triethylsilane system were made using different stoichiometries to evaluate its catalytic activity. All the experiments were carried under $\mathrm{N}_{2}$ at room temperature for $20 \mathrm{~min}$. The catalyst was removed by centrifuging at $2000 \mathrm{rpm}$ for $2 \mathrm{hr}$. A set of $0.5 \mathrm{~g}$ of $5 \% \mathrm{Pd} / \mathrm{C}$ in 10 $\mathrm{g}$ of bio-oil samples was tested by adding $0.1 \mathrm{ml}, 0.3 \mathrm{ml}$ and $0.5 \mathrm{ml}$ of TES. The viscosity decreased by $19 \%, 21 \%$ and $30 \%$ respectively. The second set of $0.5 \mathrm{ml}$ of TES in $10 \mathrm{~g}$ of biooil samples was tested with $0.1 \mathrm{~g}, 0.5 \mathrm{~g}$ and $1.0 \mathrm{~g}$ of $\mathrm{Pd} / \mathrm{C}$. The decrease of viscosity was $0 \%$, $21 \%$ and $68 \%$ respectively. The results are presented in tabular form in Table 7.

Table 7. Results from Experiment 6.

\begin{tabular}{|l|r|l|l|r|r|r|}
\hline $0.5 \mathrm{~g}$ of $5 \% \mathrm{Pd} / \mathrm{C}$ in $10 \mathrm{~g}$ of Bio-oil \\
\hline Conditions & Blank & $0.5 \mathrm{ml}$ of TES w/o Pd & $0.1 \mathrm{ml}$ of TES & $0.3 \mathrm{ml}$ of TES & $0.5 \mathrm{ml}$ of TES & Pd w/o TES \\
\hline Viscosity & 54.54 & 52.71 & 44.19 & 43.52 & 38.35 & 48.33 \\
\hline \multicolumn{7}{|l|}{} \\
\hline $0.5 \mathrm{ml}$ of TES in $10 \mathrm{~g}$ of Bio-oil \\
\hline Conditions & Blank & $0.5 \mathrm{~g}$ of Pd w/o TES & $0.1 \mathrm{~g}$ of Pd/C & $0.5 \mathrm{~g}$ of Pd/C & $1.0 \mathrm{~g}$ of Pd/C & TES w/o Pd \\
\hline Viscosity & 51.32 & 46.58 & 52.05 & 40.39 & 16.21 & 52.08 \\
\hline
\end{tabular}

The higher concentrations of TES and $5 \% \mathrm{Pd} / \mathrm{C}(0.5 \mathrm{ml} / 1 \mathrm{~g})$ resulted in the lowest viscosity of the treated bio-oil. The pathway of reduced viscosity is still not clear. It is believed that the transfer hydrogenation by TES and $\mathrm{Pd} / \mathrm{C}$ should be explored more related to bioproducts formation rather than for fuels. However, it won't be an economic choice for the stabilization of crude bio-oil.

Based on the finding that $\mathrm{Pd} / \mathrm{C}$ catalyst with TES has been found to reduce the viscosity of biooil, a scaled-up experiment was carried out to understand the chemistry of the system. $10 \mathrm{wt} \%$ of catalyst and $3 \mathrm{wt} \%$ of hydrogen donor were used for the reaction.

$2 \mathrm{~g}$ of $10 \% \mathrm{Pd} / \mathrm{C}$ was added to a set of $20 \mathrm{~g}$ of bio-oil samples. One $\mathrm{ml}$ of TES was then syringed to one sample and another sample remained without TES. Two samples were stirred at room temperature for $20 \mathrm{~min}$. Both samples then were centrifuged at $2000 \mathrm{rpm}$ for $2 \mathrm{hr}$ to remove catalyst. The samples were analyzed by elemental analysis, moisture content, $\mathrm{pH}$, GC/MS, and ${ }^{13} \mathrm{C}$ NMR.

Analysis of the products, as given in Table 8, showed that there was $2 \%$ less of carbon after TES treatment, while the amount of hydrogen and oxygen did not change. 
Table 8. Elemental Analysis of Bio-oil, Treated and Untreated with TES.

\begin{tabular}{|l|l|l|l|l|}
\hline Sample & $\mathrm{C}(\mathrm{wt} \%)$ & $\mathrm{H}(\mathrm{wt} \%)$ & $\mathrm{N} \quad(w t \%)$ & $\mathrm{O} \quad(\mathrm{wt} \%)$ \\
\hline w/o TES & 37.99 & 8.02 & $<0.05$ & 46.33 \\
\hline TES treated & 35.84 & 7.96 & $<0.05$ & 46.45 \\
\hline
\end{tabular}

The moisture content increased $\sim 2 \%$ by TES-Pd/C treatment. The water content of bio-oil without TES was $30.9 \%$ before the treatment and was $32.6 \%$ after treatment. The pH of both samples was $\sim 3$. Triethylsilane does not have an effect on the acidity of bio-oil.

Carbon-13 NMR analysis (see Table 9) showed that the percentages of aromatic and olefins were reduced while the carbohydrate sugars or alcohols and ethers increased. This suggests that the double bonds were reduced to single bonds. Based on the total carbon in the samples, $10 \%$ and $9 \%$, it suggests that both samples (before and after TES/Pd-C treatment) contain a similar amount of $\mathrm{CDCl}_{3}$ soluble carbons.

Table 9. ${ }^{13}$ C NMR Analysis of Bio-oil, Treated and Untreated with TES.

\begin{tabular}{|l|r|r|r|r|r|r|r|r|}
\hline Sample & mg & Dioxane(ul) & C (mg) of Dioxane & Calib Carbon $(\mathrm{mg})$ & $\%$ C & Ketone/ Carboxylic Acid Aromatics & Carbohydrate Aliphatics \\
\hline TES treated & 162.8 & 20 & 11.275 & 16.3156 & 10.02 & 15.83 & 18.9 & 33.16 \\
\hline Blank & 229.3 & 20 & 11.275 & 20.519 & 8.95 & 17.48 & 28.24 & 23.94 \\
\hline
\end{tabular}

The amount of poly-aromatic hydrocarbons (PAHs) decreased in the TES with $\mathrm{Pd} / \mathrm{C}$ treated sample. This suggests that the aromatics were reduced and it also agrees with the result of ${ }^{13} \mathrm{C}$ NMR spectra. It is possible that the carbon support adsorbed sufficient PAH to affect the result. TES with $\mathrm{Pd} / \mathrm{C}$ might also play a role of deoxygenation since silanols and alkyloxide silane species were detected by GC/MS in the post-treated sample. An overview of the GC/MS results for the bio-oil and the treated bio-oil are provided in Tables 10 and 11, respectively.

The results suggested that the reduction took place when bio-oil was treated with TES and 10\% $\mathrm{Pd} / \mathrm{C}$. The hydride from TES serves as the hydrogen donor and reduced the PAHs and olefins species. It was also found that the silane species can be removed simply by decanting due to the silane species (which were characterized by proton NMR) being immiscible with bio-oil.

Study Report of Triethylsilane: Based on the results of bio-oil treatment with TES, a deeper study of the TES as a reducing agent was undertaken.

Triethyl silane (CAS 617-86-7) is a silane with the molecular formula $\mathrm{C}_{6} \mathrm{H}_{16} \mathrm{Si}$. It is an alkylsilicon hydride compound with a reactive $\mathrm{Si}-\mathrm{H}$ bond. It is commonly used as a reducing agent for the reduction of various functional groups including acyl halides to aldehydes and alkyl halides, and secondary alcohols to hydrocarbons. It is also used for hydrosilanation of olefins, alcohols and phenols. 
Table 10. Qualitative Analysis by GC-MS of Blank (w/o TES) Bio-oil.

\begin{tabular}{|c|c|c|c|c|c|c|c|}
\hline 1 & $\mathrm{H}_{2} \mathrm{O}$ & 16 & $\widehat{\gamma}$ & 31 & $\mathrm{O}$ & 46 & 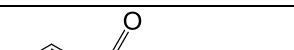 \\
\hline 2 & methanol & 17 & & 32 & & 47 & $\mathrm{O}$ \\
\hline 3 & acetone & 18 & & 33 & & 48 & \\
\hline 4 & $\mathrm{CH} 2 \mathrm{Cl} 2$ & 19 & furfural & 34 & Phenol & 49 & \\
\hline 5 & & 20 & & 35 & & 50 & \\
\hline 6 & Butanone & 21 & & 36 & & 51 & \\
\hline 7 & Acetic Acid & 22 & & 37 & & 52 & \\
\hline 8 & cyclohexene & 23 & & 38 & & 53 & \\
\hline 9 & & 24 & & 39 & & 54 & \\
\hline 10 & $\mathrm{O}_{i}$ & 25 & & 40 & & 55 & \\
\hline 11 & & 26 & 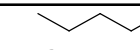 & 41 & Dodecane & 56 & \\
\hline 12 & dimethylamine & 27 & & 42 & Naphthalene & 57 & \\
\hline 13 & & 28 & & 43 & & 58 & \\
\hline 14 & & 29 & & 44 & & 59 & \\
\hline 15 & methyl acetate & 30 & & 45 & & 60 & \\
\hline
\end{tabular}


Table 11. Qualitative Analysis by GC-MS of TES treated Bio-oil.

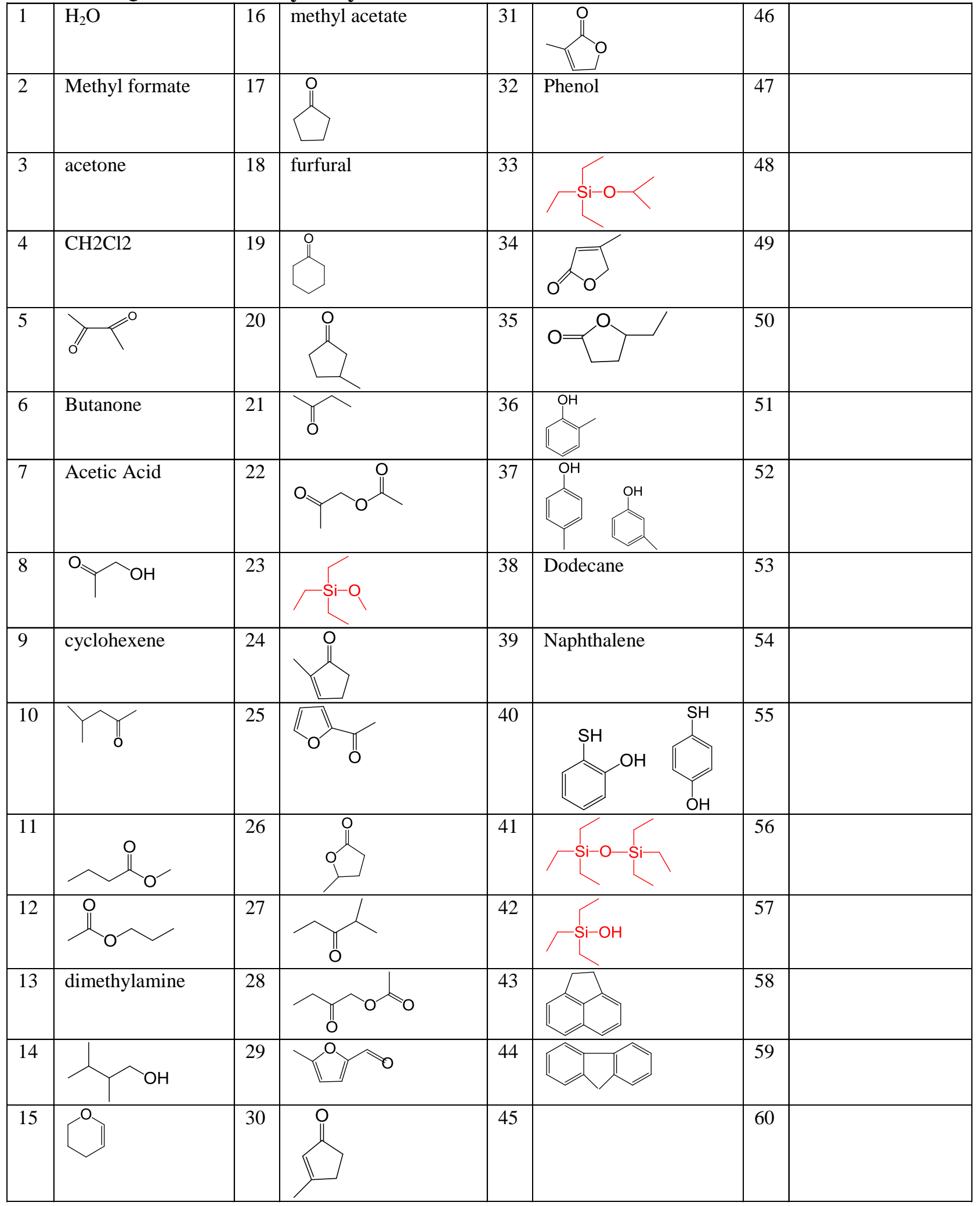


The first practical synthesis of organosilane was accomplished by F. Stanley Kipping in 1904 by the Grignard reaction. Although the current silane and silicone technologies now follow more efficient direct processes and hydrosilylation reactions (non-Grignard process), triethylsilane (TES) is one of the specialty silanes still produced by Grignard technology.

$$
\begin{array}{lll}
3 \mathrm{C}_{2} \mathrm{H}_{5} \mathrm{MgCl}+\mathrm{HCl} 3 \mathrm{Si} & \rightarrow\left(\mathrm{C}_{2} \mathrm{H}_{5}\right)_{3} \mathrm{SiH} & \text { or } \\
3 \mathrm{C}_{2} \mathrm{H}_{5} \mathrm{MgCl}+\mathrm{Cl}_{4} \mathrm{Si} & \longrightarrow\left(\mathrm{C}_{2} \mathrm{H}_{5}\right)_{3} \mathrm{SiCl} \stackrel{\mathrm{LiAlH}_{4}}{\longrightarrow}\left(\mathrm{C}_{2} \mathrm{H}_{5}\right)_{3} \mathrm{SiH}
\end{array}
$$

There are 89 suppliers of TES worldwide, including 38 in China and 28 in US and 23 other global suppliers. Nanjing Lanya Chemical Co., Ltd is one of the biggest suppliers of TES in China, producing $400 \mathrm{Mt}$ per year. The major suppliers in the US are Gelest, TCI America, BetaPharma, Alfa Aesar, and Advanced Synthesis.

The important applications of TES are for pharmaceutical intermediates syntheses. The commercial price ranges from $\$ 1.00 / \mathrm{g}$ to $\$ 4.03 / \mathrm{g}$.

Typical reactions of TES are as follows:

1. Hydrolysis or methanolysis with catalyst, such as $\mathrm{Pd}, \mathrm{Ir}$ or $\mathrm{HCl}$, the $\mathrm{Si}-\mathrm{H}$ bond breaks to produce $\mathrm{H}_{2}$ and silanols.

$$
\begin{aligned}
& \left.\mathrm{C}_{2} \mathrm{H}_{5}\right)_{3} \mathrm{Si}^{+}+ \\
& \mathrm{OH}^{-}
\end{aligned} \longrightarrow \begin{aligned}
& \left(\mathrm{C}_{2} \mathrm{H}_{5}\right)_{3} \mathrm{SiOH} \\
& \left(\mathrm{C}_{2} \mathrm{H}_{5}\right)_{3} \mathrm{SiOR}
\end{aligned}
$$

2. Dimerization: Two siloxane units with Si-O bonds form a dimer according to the basic silane molecule.

$$
\left.2\left(\mathrm{C}_{2} \mathrm{H}_{5}\right)_{3} \mathrm{SiOH} \longrightarrow\left(\mathrm{C}_{2} \mathrm{H}_{5}\right)_{3} \mathrm{Si}-\mathrm{O}-\mathrm{Si}_{(} \mathrm{H}_{5} \mathrm{C}_{2}\right)_{3}
$$

Once the triethylsilane forms a silanol or a dimer, it is difficult to recycle back to TES because of the extremely high Si-O bond energy, $452 \mathrm{~kJ} / \mathrm{mol}$. The Si-O bond is uncommonly stable and is not broken either by strong oxidizing agent, such as chlorine, or reducing agent, such as sodium or lithium.

Triethylisilane is an excellent hydrogen donor coupling with $\mathrm{Pd}$ for catalytic transfer hydrogenation. However, it is not a practical agent for the stabilization of crude bio-oil because it is not feasible to reprocess the dimer to TES once it forms siloxane unit (RSiO-).

Conclusion: The study of catalytic transfer hydrogenation for stabilizing bio-oil has not shown promise. Although triethylsilane and palladium/carbon can lower the viscosity of bio-oil, the method is not considered to be economical due to the lack of an economical recycle/regeneration of the hydrogen donor.

\section{SubTask number 3.2-Hydrothermal Treatment}

Approach: Hydrothermal treatment of fast pyrolysis bio-oil was performed on the basis of experience with hydrothermal liquefaction (HTL) of biomass. Like HTL, no catalyst nor hydrogen was added to the reaction system. Thermally driven chemistry in the pressurized environment was allowed with the expected outcome that the most reactive functional groups 
would be eliminated by reaction thus "stabilizing" the bio-oil for longer-term storage or for higher temperature processing. At the start of the project, the experimental plan was adjusted from the initially proposed effort in light of recent information from Europe (the BIOCOUP project) exploring this same concept. In a more recent publication from that group ${ }^{\mathrm{xii}}$ the hydrothermal treatment was performed at temperatures from 200 up to $350^{\circ} \mathrm{C}$ and the authors found that the treated bio-oil phase separated into a heavy oil phase and a lighter, mostly water phase. They concluded that, although measureable deoxygenation occurred, the resulting product had a significant increase in molecular weight. Based on these results this project has focused on hydrothermal treatment at lower temperatures wherein the bio-oil does not phase separate. The experiments were undertaken in a stirred batch reactor initially in order to scope out the effects of the operating parameters of time and temperature and determine appropriate ranges to test in a continuous-flow rector system.

\section{Experimental Results:}

\section{Aging Test}

It is now clear that the variation of the bio-oil sampling or inconsistencies in the method execution can lead to conflicting results regarding phase separation and viscosity increase of biooil as assessed in the thermal aging test. However, aging test results acquired with an $80^{\circ} \mathrm{C}$ hold temperature appear to be more consistent and reproducible than those at $90^{\circ} \mathrm{C}$ as specified by DOE for this solicitation. The aging test $\left(24 \mathrm{hr} @ 90^{\circ} \mathrm{C}\right)$ shows a $98 \%$ increase in viscosity for the bio-oil product (43.72 to $86.59 \mathrm{cSt}$ ) but only a 37\% increase at reduced aging (24 hr@ $80^{\circ} \mathrm{C}$ ). This trend is documented in Table 12 with results of aging tests at lower temperatures of $70^{\circ} \mathrm{C}$ and $60^{\circ} \mathrm{C}$ also. Elsewhere ${ }^{\text {xiii }}$ The $24 \mathrm{hr}$ aging at $80^{\circ} \mathrm{C}$ has been correlated with storage at room temperature for a year.

\begin{tabular}{|c|c|c|c|c|c|c|c|c|c|c|c|c|}
\hline \multicolumn{13}{|c|}{ Table 12. Stability test per standard aging method } \\
\hline & \multicolumn{12}{|c|}{ stirred batch tests with time at temperature } \\
\hline & \multirow{2}{*}{\multicolumn{12}{|c|}{ density/viscosity by ASTM D-7024 (ref to D-445) }} \\
\hline & & & & & & & & & & & & \\
\hline & \multirow[b]{2}{*}{ time } & \multirow[b]{2}{*}{ liters gas } & \multirow[b]{2}{*}{ visc@40C c } & \multirow[b]{2}{*}{ dens@40C } & \multicolumn{2}{|c|}{$24 \mathrm{hr}$ stability at $90 \mathrm{C}$} & \multicolumn{2}{|c|}{$24 \mathrm{hr}$ stability at $80 \mathrm{C}$} & \multicolumn{2}{|c|}{$24 \mathrm{hr}$ stability at $70 \mathrm{C}$} & \multirow{2}{*}{\multicolumn{2}{|c|}{$\begin{array}{l}24 \mathrm{hr} \text { stability at } 60 \mathrm{C} \\
\text { visc@40C dens@40C }\end{array}$}} \\
\hline temp & & & & & visc@40C & dens@40C、 & visc@40C & dens@40C & visc@40C o & dens@40C & & \\
\hline 4 & --- & --- & 43.724 & 1.2093 & 86.589 & 1.2089 & 60.058 & 1.2102 & 59.096 & 1.2101 & 46.586 & 1.2100 \\
\hline & & & & & & & & & & & & \\
\hline 100 & 10 & 0.00 & 45.258 & 1.2113 & 246 & 1.0629 & 77.831 & 1.2026 & & & & \\
\hline 100 & 20 & 0.00 & 51.365 & 1.2117 & & & 67.803 & 1.2125 & & & & \\
\hline 100 & 40 & 0.01 & 57.670 & 1.2132 & two $p$ & hases & 78.761 & 1.2167 & & & & \\
\hline 100 & 50 & 0.01 & 61.391 & 1.2115 & $228^{*}$ & 1.1551 & 80.627 & 1.2101 & & & & \\
\hline 100 & 80 & 0.05 & 67.560 & 1.2148 & two $p$ & hases & 82.514 & 1.2005 & & & & \\
\hline 100 & 100 & 0.10 & 72.119 & 1.2069 & & & 74.092 & 1.2064 & & & & \\
\hline 110 & 10 & 0.01 & 48.666 & 1.2109 & & & 80.956 & 1.1863 & & & & \\
\hline 110 & 30 & 0.01 & 48.666 & 1.2109 & $1444^{*}$ & 0.9 & 107.230 & 1.1996 & & & & \\
\hline & & & & & ${ }^{*}$ not stable & reading and $n$ & went to $2 \mathrm{ph}$ & lases after coc & oling in refric & gerator & & \\
\hline 120 & 10 & 0.01 & 49.302 & 1.2094 & 129 & 1.1973 & 92.662 & 1.1976 & $90 \mathrm{C} 2$ phas & ses after co & oling in refri & igerator \\
\hline 120 & 50 & 0.02 & 74.556 & 1.2085 & TBD & TBD & 147.59 & 1.1859 & & & & \\
\hline 120 & 60 & 0.06 & single phas & se recovered & d, but two ph & lases after refi & frigeration & & & & & \\
\hline & & & & & & & & & & & & \\
\hline 140 & 40 & 0.28 & two phases & & & & & & & & & \\
\hline 140 & 80 & 0.32 & two phases & & & & & & & & & \\
\hline & & & & & & & & & & & & \\
\hline 150 & 60 & 0.45 & two phases: & s: $111.04 \mathrm{~g} \mathrm{he}$ & neavy oil 12,7 & 783 cSt @50C & $C$ and 1.237 & $71 \mathrm{~g} / \mathrm{ml}, 73.44$ & $4 \mathrm{~g}$ aqueous & & & \\
\hline & & & & & & & & & & & & \\
\hline 200 & 20 & 2.51 & two phases: & s:56.93g wax & xy solid, 154 & $.29 \mathrm{~g}$ yellow a & aqueous & & & & & \\
\hline
\end{tabular}


This temperature/aging relationship was further confirmed by some extended time measurements in the viscometer at constant temperature. As shown in Table 13, a gradual increase in viscosity by $2 \mathrm{cSt}$ is measured at $70^{\circ} \mathrm{C}$ over a day's time. At $80^{\circ} \mathrm{C}$ there was a similar gradual change of about $2 \mathrm{cSt}$ for the first 16 hours then a dramatic change occurred, possibly due to phase separation, with a more severe increase of viscosity and drop in density following. At $90^{\circ} \mathrm{C}$ the measurements were only possible for a few hours before the oil changed to such a degree that further measurements were not possible.

\begin{tabular}{|l|l|l|l|l|l|l|}
\hline \multicolumn{7}{|c|}{ Table 13. Extended Time Results for Viscosity Measurement } \\
\hline temp & initial visc & initial dens & final visc & final dens & \multicolumn{1}{l|}{ hours } & description of test results \\
\hline $70^{\circ} \mathrm{C}$ & $9.728 \mathrm{cSt}$ & $1.183 \mathrm{~g} / \mathrm{ml}$ & $11.004 \mathrm{cSt}$ & $1.1834 \mathrm{~g} / \mathrm{ml}$ & 25.75 & slight decrease initial hour then steady gradual increase \\
\hline $80^{\circ} \mathrm{C}$ & $6.638 \mathrm{cSt}$ & $1.174 \mathrm{~g} / \mathrm{ml}$ & $28.732 \mathrm{cSt}$ & $1.1698 \mathrm{~g} / \mathrm{ml}$ & 21.60 & steady increase for 16 then dramatic change \\
\hline $90^{\circ} \mathrm{C}$ & $4.877 \mathrm{cSt}$ & $1.165 \mathrm{~g} / \mathrm{ml}$ & $5.283 \mathrm{cSt}$ & $1.1642 \mathrm{~g} / \mathrm{ml}$ & 5.75 & measurements became unsteady after short period \\
\hline
\end{tabular}

\section{Batch Reactor Tests}

Initial tests of hydrothermal post-processing bio-oil stabilization were performed in a batch reactor system. The standard bio-oil (Kentucky oak-derived from NREL) was loaded into the batch reactor sealed and heated to the target temperature and held for the target time before cooling and recovering the treated bio-oil for analysis. The reactor air space was purged with nitrogen before heating to minimize reaction of the bio-oil with oxygen. The reactor was stirred during the test. Heatup time varied with the target temperature but a typical time was 15 min to $100^{\circ} \mathrm{C}$, with only 5 minutes at temperatures above $80^{\circ} \mathrm{C}$, before reaching the final temperature.

Table 12 provides the range of time and temperature tested. In all cases the bio-oil was measured for viscosity after the hydrothermal treatment and then put through the aging test with the viscosity measured again following the aging. Following the initial round of tests at 100$200^{\circ} \mathrm{C}$, the experimental plan of batch reactor tests was extended to more tests to optimize the process in a reduced range of operating parameters.

Hydrothermal treatment produced a single phase bio-oil product only at the less severe conditions and we limited our further consideration to only those products. Hydrothermal treatment typically produces a more viscous bio-oil. The viscosity of the bio-oil correlates with the severity of the hydrothermal treatment (time and temperature) and also the yield of gas product, which is typically very low. Subsequent aging of these treated bio-oil products suggested that they are more stable in that the increase of viscosity is a lower percentage of the starting viscosity (after hydrothermal treatment). However, the results from the batch tests were somewhat inconsistent. Use of the $90^{\circ} \mathrm{C}$ temperature in the aging test was particularly problematic and earlier results were difficult to reproduce. Results at the $80^{\circ} \mathrm{C}$ temperature were used to suggest the improved stability.

We also performed hydrothermal processing with an alkali "catalyst" ( $\mathrm{pH}$ modifier). A series of batch hydrothermal processing tests were performed similar to the batch tests described above. Three tests were performed for $60 \mathrm{~min}$ at $100^{\circ} \mathrm{C}$ or at $150^{\circ} \mathrm{C}$ using sodium hydroxide, sodium carbonate or no alkali. In all the tests at $150^{\circ} \mathrm{C}$ the bio-oil separated into two phases with a heavy solid bottom phase, described as "a pliable wax". In the $100^{\circ} \mathrm{C}$ tests the bio-oil viscosity increased compared to the starting bio-oil; however, the aging test results provided some interesting levels of stabilization. The results shown in Table 14 suggest that the starting bio-oil, 
measured at $47.87 \mathrm{cSt} @ 40^{\circ} \mathrm{C}$ with a density of $1.210 \mathrm{~g} / \mathrm{ml}$, increased significantly in viscosity by the hydrothermal treatment (similar to the result in Table 12 for $50 \mathrm{~min}$ at $100^{\circ} \mathrm{C}$ ). The alkali catalyzed hydrothermally treated bio-oil showed higher viscosity than the blank. In the aging test at $90^{\circ} \mathrm{C}$ all the samples phase separated, but the phases could be stirred together to allow measurement of the aged treated-bio-oil, but with a much increased variability in the measurement. These tests suggested that the sodium carbonate hydrothermally treated bio-oil was more stable than the blank. The sodium hydroxide hydrothermally treated bio-oil aged to a heavy viscous product. Aging at $80^{\circ} \mathrm{C}$ produced less dramatic effects although the treated-biooil phase separated, as in the $90^{\circ} \mathrm{C}$ aging tests, and required stirring to achieve a useful measurement. During the $80^{\circ} \mathrm{C}$ aging test, with residual alkali present from the hydrothermal treatment, the viscosity of the treated bio-oil actually appeared to decrease.

Table 14. Stability Test for Alkali Hydrothermally-Treated Products
\begin{tabular}{|l|c|c|c|c|c|c|}
\hline stirred batch tests with 60 min at 100C \\
\hline density/viscosity by ASTM D-7024 (ref to D-445) \\
\hline & & & $24 \mathrm{hr}$ stability at $90 \mathrm{C}$ & $24 \mathrm{hr}$ stability at $80 \mathrm{C}$ \\
\hline alkali & visc@ $40^{\circ} \mathrm{C}$ & dens@ $@ 40^{\circ} \mathrm{C}$ & visc@ $40^{\circ} \mathrm{C}$ & dens@ $40^{\circ} \mathrm{C}$ & visc@ $@ 40^{\circ} \mathrm{C}$ & dens@ $40^{\circ} \mathrm{C}$ \\
\hline none & 61.61 & 1.214 & 164.75 & 1.198 & 65.132 & 1.204 \\
\hline carbonate & 66.71 & 1.206 & 89.13 & 1.210 & 63.102 & 1.213 \\
\hline hydroxide & 71.77 & 1.207 & 8500 & 1.221 & 67.831 & 1.128 \\
\hline
\end{tabular}

red font indicates erratic measurements suggesting phase separation

\section{Continuous-Flow Reactor Tests}

Tests of hydrothermal post-processing bio-oil stabilization were also performed in a continuousfeed, plug-flow tubular reactor system. Continuous-flow tests were performed to determine if more consistent results could be obtained than in the batch tests. For these tests, the standard bio-oil (Kentucky oak-derived from NREL) was pumped into the heated reactor tube at a range of flow rates and bed temperatures. The treated-bio-oil was cooled and recovered for analysis. No catalyst or reactive gas was used in the hydrothermal treatment. The reactor tube was a 3/8" OD X 0.035" wall 316SS tube with a 30" length inside a 3/4" jacket, through which heating oil was passed.

Table 15 below provides the range of flow-rate and temperature tested. In all cases the bio-oil was measured for viscosity after the hydrothermal treatment and then put through the aging test with the viscosity measured again following the aging. Following the initial round of tests at $100-120^{\circ} \mathrm{C}$, the experiment was repeated over a broader range of flow rates to optimize the process operating parameters.

The products from the continuous-flow tests actually had properties more similar to the bio-oil starting material. Viscosities, in all cases, were less. Densities were both slightly less and more. Subsequent aging of these hydrothermally treated bio-oil products suggested that they are more stable in that the increase of viscosity is a lower percentage of the starting viscosity (after hydrothermal treatment). However, the results were somewhat inconsistent. Use of the $90^{\circ} \mathrm{C}$ temperature in the aging test was particularly problematic. Results at the $80^{\circ} \mathrm{C}$ temperature were used to suggest the improved stability. Whereas the starting bio-oil (in the first test) aged to $145 \%$ at $90^{\circ} \mathrm{C}$ and $35 \%$ at $80^{\circ} \mathrm{C}$, the treated bio-oil $\left(4 \mathrm{LHSV} @ 100^{\circ} \mathrm{C}\right.$ ) aged only $27 \%$ at $90^{\circ} \mathrm{C}$ and $26 \%$ at $80^{\circ} \mathrm{C}$, suggesting a more thermally stable bio-oil. This treatment was at the lower temperature while higher temperatures produced products with aging increases closer to or 
greater than the starting bio-oil. The samples from the second test did not confirm this improved stability.

\begin{tabular}{|c|c|c|c|c|c|c|c|c|c|}
\hline \multirow[b]{2}{*}{ temp } & \multirow[b]{2}{*}{ LHSV } & \multirow[b]{2}{*}{ pressure } & \multicolumn{2}{|l|}{ after treatment } & \multicolumn{3}{|c|}{ after aging 90C } & \multicolumn{2}{|c|}{ after aging $80 \mathrm{C}$} \\
\hline & & & visc, cSt@40º & dens g/ml@40ㄷ & visc & $\Delta$ visc & dens & visc & dens \\
\hline feed & -- & -- & $45.55 / \mathrm{NA}$ & $1.210 / \mathrm{NA}$ & 111.7 & $145 \%$ & 1.142 & 61.31 & 1.212 \\
\hline $100^{\circ} \mathrm{C}$ & 0.55 & 200 psig & $48.52 / 57.52$ & $1.209 / 1.210$ & $\mathrm{NA}$ & & $\mathrm{NA}$ & 70.18 & 1.194 \\
\hline $100^{\circ} \mathrm{C}$ & 1.1 & 180 psig & $44.20 / 40.55$ & $1.209 / 1.208$ & $\mathrm{NA}$ & & $\mathrm{NA}$ & 65.85 & 1.208 \\
\hline $100^{\circ} \mathrm{C}$ & 4.0 & 180 psig & $43.29 / 47.50$ & $1.210 / 1.212$ & 55.17 & $27.4 \%$ & 1.198 & 59.67 & 1.207 \\
\hline $110^{\circ} \mathrm{C}$ & 2.5 & 200 psig & $43.75 / 48.48$ & $1.209 / 1.208$ & 206.4 & $371 \%$ & 1.132 & 64.82 & 1.200 \\
\hline $120^{\circ} \mathrm{C}$ & 8.1 & 200 psig & $43.65 / 49.49$ & $1.209 / 1.210$ & 104.3 & $139 \%$ & 1.165 & 64.74 & 1.207 \\
\hline feed & -- & -- & 48.64 & 1.206 & 81.17 & $66.9 \%$ & 1.208 & 75.68 & 1.210 \\
\hline $100^{\circ} \mathrm{C}$ & 2.6 & 350 psig & 44.37 & 1.208 & 78.51 & & 1.205 & 72.99 & 1.194 \\
\hline $100^{\circ} \mathrm{C}$ & 4.4 & 350 psig & 43.63 & 1.202 & 88.84 & & 1.206 & 82.16 & 1.195 \\
\hline $120^{\circ} \mathrm{C}$ & 9.9 & 350 psig & 43.26 & 1.208 & 88.18 & & 1.210 & 77.84 & 1.194 \\
\hline $120^{\circ} \mathrm{C}$ & 13.4 & 350 psig & 44.50 & 1.210 & 92.65 & & 1.211 & 68.81 & 1.145 \\
\hline
\end{tabular}

red font indicates erratic measurements suggesting phase separation

blue and black represent two sets of analyses of the same oil samples

The analyses of these products otherwise, as shown in Table 16, are similarly inconsistent. The analyses of the samples from the first test suggest that hydrothermal treatment will dehydrate the oil components in that the carbon content increases while the hydrogen and oxygen content decrease. As a corollary, the $\mathrm{H} / \mathrm{C}$ decreases while the moisture content increases. However, there appears to be no relation to the severity of the processing, nor does the TAN correlate with the elemental composition. The samples from the second test show trends in the opposite direction - the oxygen content is higher as is the $\mathrm{H} / \mathrm{C}$ ratio. In the end, it may be that the difficulty in sampling these viscous oils with high moisture contents due to the inhomogeneity makes such conclusions about such small differences dubious.

\begin{tabular}{|l|r|c|l|l|l|l|l|l|l|}
\hline \multicolumn{2}{|l|}{ Table 16. Results of Analyses of Samples from Continuous Flow Tests } \\
\hline & & & \multicolumn{2}{l|}{ average of two, calculated to a dry basis } & & \\
\hline temp & LHSV & pressure & Carbon & Hydrogen & Oxygen, wt\% & H/C & moisture & TAN \\
\hline & & & wt\% & wt\% & by difference & atomic & wt\% & $\mathrm{mg} \mathrm{KOH/g}$ \\
\hline feed & -- & -- & 53.98 & 6.62 & 39.40 & 1.46 & 22.80 & 96.44 \\
\hline $100^{\circ} \mathrm{C}$ & 0.55 & $200 \mathrm{psig}$ & 56.66 & 6.19 & 37.15 & 1.30 & 26.23 & 103.7 \\
\hline $100^{\circ} \mathrm{C}$ & 1.1 & $180 \mathrm{psig}$ & 55.77 & 6.31 & 37.92 & 1.35 & 24.93 & 98.43 \\
\hline $100^{\circ} \mathrm{C}$ & 4.0 & $180 \mathrm{psig}$ & 55.69 & 6.43 & 37.88 & 1.37 & 25.24 & 108.7 \\
\hline $110^{\circ} \mathrm{C}$ & 2.5 & $200 \mathrm{psig}$ & 54.77 & 6.43 & 38.80 & 1.40 & 23.82 & 113.2 \\
\hline $120^{\circ} \mathrm{C}$ & 8.1 & $200 \mathrm{psig}$ & 54.86 & 6.38 & 38.76 & 1.39 & 24.44 & 103.6 \\
\hline feed & -- & -- & 55.05 & 6.26 & 38.60 & 1.35 & 23.36 & 111.3 \\
\hline $100^{\circ} \mathrm{C}$ & 2.6 & $350 \mathrm{psig}$ & 54.67 & 6.42 & 38.81 & 1.40 & 23.44 & 106.8 \\
\hline $100^{\circ} \mathrm{C}$ & 4.4 & $350 \mathrm{psig}$ & 54.83 & 6.49 & 38.58 & 1.41 & 22.90 & 108.9 \\
\hline $120^{\circ} \mathrm{C}$ & 9.9 & $350 \mathrm{psig}$ & 54.68 & 6.53 & 38.66 & 1.42 & 23.00 & 100.2 \\
\hline $120^{\circ} \mathrm{C}$ & 13.4 & $350 \mathrm{psig}$ & 54.44 & 6.52 & 38.94 & 1.42 & 22.66 & 104.9 \\
\hline
\end{tabular}

A final continuous-flow test was performed at optimized conditions for hydrothermal processing $\left(100^{\circ} \mathrm{C}+/-1,4.7\right.$ LHSV) to produce sufficient feedstock (6.9 liters) for a catalytic hydroprocessing test. This product was sampled during the run and showed inconsistent results in the aging test at $90^{\circ} \mathrm{C}$ (one sample was more stable than the raw bio-oil and one sample less stable). These tests were then repeated with the composite product and all the results are presented in Table 17. 
\begin{tabular}{|l} 
Table 17. Results from Long-Term Continuous Flow Test, $76.3 \mathrm{hr}$ on stream \\
\hline
\end{tabular}

\begin{tabular}{|l|c|c|c|c|c|c|l|l|l|}
\hline \multicolumn{9}{|c|}{} & \multicolumn{2}{c|}{ after treatment } & \multicolumn{2}{l|}{ after aging $90 \mathrm{C}$} & \multicolumn{2}{l|}{ after aging $80 \mathrm{C}$} \\
\hline temp & LHSV & pressure & sample & visc, cSt@40 & dens $\mathrm{g} / \mathrm{ml} @ 40^{\circ} \mathrm{C}$ & visc & dens & visc & dens \\
\hline feed & -- & -- & -- & 46.05 & 1.209 & NA & NA & NA & NA \\
\hline $100^{\circ} \mathrm{C}$ & 4.0 & $350 \mathrm{psig}$ & $0030-430$ & 44.98 & 1.148 & 73.51 & 1.197 & NA & NA \\
\hline $100^{\circ} \mathrm{C}$ & 4.0 & $350 \mathrm{psig}$ & $430-830$ & 45.81 & 1.207 & 117.65 & 1.111 & NA & NA \\
\hline $100^{\circ} \mathrm{C}$ & 4.0 & $350 \mathrm{psig}$ & composite & 51.32 & 1.210 & 96.58 & 1.208 & 93.81 & 1.202 \\
\hline
\end{tabular}

red font indicates erratic measurements suggesting phase separation

\section{Hydroprocessing of Hydrothermally Treated Bio-oil}

The product was processed through the continuous-flow catalytic hydrotreater and upgraded product was produced. The results were similar to those with the raw bio-oil in that fouling in the catalyst bed was not alleviated and resulted in termination of the run after $29 \mathrm{hr}$.

The hydroprocessing experiment was undertaken in the bench-scale hydrotreater system in the Chemical Engineering Laboratory at PNNL. That system included a fixed-bed catalytic reactor with required feeding and product recovery components. The bio-oil was fed by a high-pressure metering syringe pump. Hydrogen was introduced into the reactor via high-pressure lines and mass flow controller from a gas cylinder manifold. The products were cooled and collected in a dual cylinder sampling system with the uncondensed gases sampled, measured and vented. The recovered liquid products were weighed and sampled for further analysis. Manually recovered gas samples were analyzed by gas chromatography. A schematic drawing of the reactor system is shown below in Figure 2.

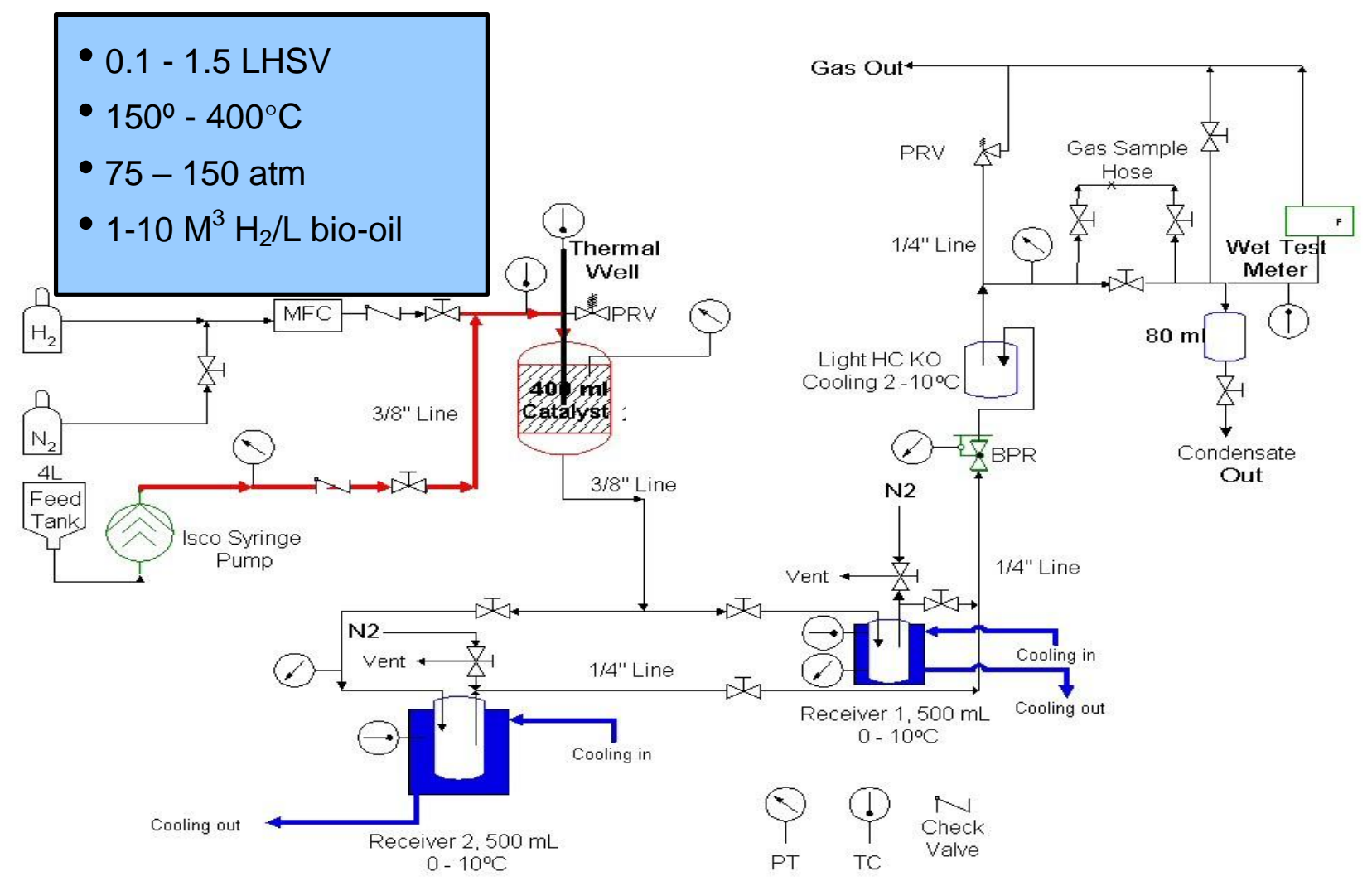

Figure 2. Schematic of bench-scale hydrotreater at PNNL 
A cobalt/molybdenum on carbon catalyst was used in a bench-scale, fixed-bed reactor to hydrogenate the bio-oil and produce an upgraded bio-oil. The $\mathrm{CoMo} / \mathrm{C}$ catalyst was identified in earlier experimentation at PNNL (invention report \#16665-E). The operating conditions included a two-stage temperature of $252^{\circ} \mathrm{C}$ and $404^{\circ} \mathrm{C}, 1938 \mathrm{psig}$, and a 0.15 liters stabilized biooil per liter of catalyst bed per hour Liquid Hourly Space Velocity (LHSV). The mass balance for the two operating windows ranged from $88 \%$ to $96 \%$; however, the carbon balance was not so good at $68 \%$ to $78 \%$. The oil product yield was $35 \%$ on a volume basis and $30-33 \%$ on a mass basis. As shown in Table 18, the hydroprocessing with the hydrothermally stabilized biooil reduced the oil color, density, and TAN dramatically due to the nearly complete deoxygenation. Although unquantified, the viscosity was also dramatically reduced from the starting $51 \mathrm{cSt} @ 40^{\circ} \mathrm{C}$. Over the 29 hour time on stream (TOS) the catalyst activity fell, resulting in an increasing density and more intensely colored product with reduced hydrogen (and $\mathrm{H} / \mathrm{C}$ ratio). The residual oxygen content increased over TOS, as did the nitrogen and sulfur, although the acid number remained essentially unchanged. The hydrogen consumption also dropped dramatically from 656 standard liter $\mathrm{H}_{2}$ per liter bio-oil early on in the test to $445 \mathrm{l} / \mathrm{l}$ at the end. There remain questions as to the quality of catalyst used in this single test. The separate aqueous phase was effectively $2 / 3$ by volume of the feed bio-oil, but it carried less than $1 \%$ of the carbon in the feed. The gas product accounted for $20 \%$ of the carbon in the feed with only a little bit of carbon dioxide and mostly methane with lesser amounts of higher hydrocarbons .

\begin{tabular}{|l|c|c|c|c|c|c|c|c|c|}
\hline \multicolumn{1}{|l|}{ Table 18. Results of Hydrotreating Hydrothermally-treated Bio-oil } \\
\hline TOS & density & color & Carbon & Hydrogen & Oxygen & $\mathrm{N}+\mathrm{S}$ & $\mathrm{H} / \mathrm{C}$ & moisture & TAN \\
\hline hr & $\mathrm{g} / \mathrm{ml}$ & & wt $\%$ & wt \% & wt \% & wt \% & atomic & wt\% & $\mathrm{mg} \mathrm{KOH} / \mathrm{g}$ \\
\hline feed & 1.21 & drk brn & 42.88 & 7.69 & 43.25 & 0.146 & 1.43 & 22.51 & 96.66 \\
\hline $4.5-7.5$ & 0.79 & It red & 85.76 & 13.15 & 0.27 & $<0.05$ & 1.82 & 0.003 & 0.64 \\
\hline $19.5-29$ & 0.89 & orange & 86.05 & 10.94 & 0.89 & 0.086 & 1.51 & 0.101 & 0.60 \\
\hline
\end{tabular}

Coking of the catalyst bed by the bio-oil in the low-temperature portion was identified as a significant problem in the operation of the hydrotreatment. Use of the temperature zones in the catalyst bed was an attempt to stabilize the bio-oil prior to full hydrotreatment at higher temperature. The fact that the "stabilized" bio-oil fouled the catalyst bed and caused an increased pressure drop suggests that the hydrothermal treatment had little value in improving the processability of fast pyrolysis bio-oil.

Conclusions: Hydrothermal treatment of fast pyrolysis bio-oil produces "stabilized" bio-oils of inconsistent quality, possibly due to imprecise temperature measurement or inconsistent sampling due to the tendency toward inhomogeneity of the bio-oil. Clearly, more severe thermal treatment results in phase separation of the bio-oil yielding a more dense, more viscous (tar) phase and a less dense, less viscous (aqueous) phase. By careful control of the severity (residence time and temperature) the phase separation can be controlled, for the most part. A maximum allowable severity for hydrothermal treatment was found at $4 \mathrm{LHSV}$ and $100^{\circ} \mathrm{C}$, which allowed a single phase product to be recovered. The hydrothermally treated bio-oil is often (although inconsistently) more viscous than the starting bio-oil. In the thermal aging test, the hydrothermally treated bio-oil typically showed a lesser increase in viscosity (better 
stability). The 24-hour thermal aging test generally is functional when practiced at $80^{\circ} \mathrm{C}$ but is very inconsistent when practiced at $90^{\circ} \mathrm{C}$. At $90^{\circ} \mathrm{C}$ it often leads to phase separation so that the viscosity change cannot be determined. It was not possible to show that the hydrothermally treated bio-oil was more stable than fast pyrolysis bio-oil when processed in a fixed-bed catalytic hydrotreater to produce hydrocarbon fuel products; a pressure drop still developed over the catalyst bed during operation and evidence of fouling of the catalyst particles when recovered following the test.

\section{Conclusions}

The study of catalytic transfer hydrogenation for stabilizing bio-oil has not shown promise. The many combinations of donor and catalyst provided little indication of useful reaction. Although treatment with triethylsilane hydrogen donor solvent and palladium on carbon catalyst can lower the viscosity of bio-oil, the method is not considered to be economical due to the lack of an economical recycle/regeneration of the hydrogen donor.

Hydrothermal treatment of fast pyrolysis bio-oil produces "stabilized" bio-oils of inconsistent quality, possibly due to imprecise temperature measurement or inconsistent sampling due to the tendency toward inhomogeneity of the bio-oil. Clearly, more severe thermal treatment results in phase separation of the bio-oil yielding a more dense, more viscous (tar) phase and a less dense, less viscous (aqueous) phase. By careful control of the severity (residence time and temperature) the phase separation can be controlled, for the most part. A maximum allowable severity for hydrothermal treatment was found at $4 \mathrm{LHSV}$ and $100^{\circ} \mathrm{C}$, which allowed a single phase product to be recovered. The hydrothermally treated bio-oil is often (although inconsistently) more viscous than the starting bio-oil. In the thermal aging test, the hydrothermally treated bio-oil typically showed a lesser increase in viscosity (better stability). The 24-hour thermal aging test generally is functional when practiced at $80^{\circ} \mathrm{C}$ but is very inconsistent when practiced at $90^{\circ} \mathrm{C}$. At $90^{\circ} \mathrm{C}$ it often leads to phase separation so that the viscosity change cannot be determined. It was not possible to show that the hydrothermally treated bio-oil was more stable than fast pyrolysis bio-oil when processed in a fixed-bed catalytic hydrotreater to produce hydrocarbon fuel products; a pressure drop still developed over the catalyst bed during operation and evidence of fouling of the catalyst particles when recovered following the test.

\section{References}

\footnotetext{
${ }^{\mathrm{i}}$ Muniz, K. "Bifunctional Metal-Ligand Catalysis: Hydrogenations and New Reactions within the Metal-(Di)amine Scaffold" Angew Chemie, International Edition, 2005, volume 44, 6622 - 6627.

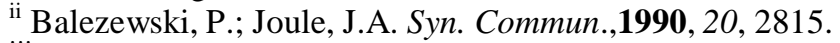

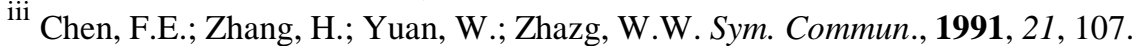

${ }^{\text {iv }}$ Botta, M.; Summa, V.; Saladino, R.; Nicoletti, R. Syn. Commun.,1991, 21, 2181.

${ }^{v}$ Barrett, A.G.M.; Spilling, C.D. Tetrahedron Lett., 1988, 29, 5733.

${ }^{v i}$ Balicki, R. Synthesis, 1989, 645.

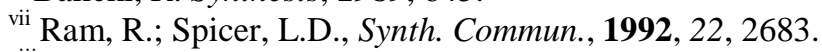

viii Alonso, F.; Riente, P.; Yus, M., Tetrahedron Lett. 2008, 49, 1939.
} 
${ }^{\mathrm{ix}}$ Mehdi, H.; Fabos, V.; Tuba, R.; Bodor, A.; Mika, L.T.; Horvath, I.T., Top Catal, 2008, 48, 49; Naskar, S.; Bhattacharjee, M., Tetrahedron Lett., 2007, 48, 465; Cortez, N.; Aguirre, G.; Parra-Hake, M.; Somanathan, R., Tetrahedron Lett., 2007, 48, 4335.

${ }^{x}$ Mandal, P. K. and McMurray, J. S. J. Org. Chem. 2007, 72, 6599

${ }^{x i}$ Menozzi, C.; Dalko, P. I. and Cossy, J. Synlett 2005, 2449

${ }^{x i i}$ Mercader, F. deM.; Groeneveld, M.J.; Kersten, S.R.A.; Venderbosch, R.H.; Hogendoorn, J.A. Fuel, 2010, 89, 2829.

xiii Oasmaa, A.; Leppämäki, E.; Koponen, P.; Levander, J.; Tapola, E. Physical characterization of biomass-based pyrolysis liquids: Application of standard fuel oil analyses. \#306. Technical Research Centre of Finland, Espoo, Finland, 1997. 